MiscellaneA BiograficZne

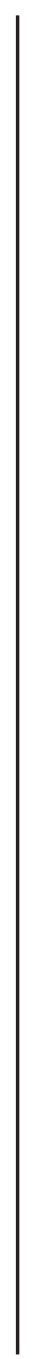


DOI: 10.32089/WBH.PHW.2019.3(269).0005

Grzegorz Sojda: orcid.org/0000-0002-7892-8146

Grzegorz Śliżewski: orcid.org/0000-0001-6123-2241

GrZEgORZ SOJDA

GRZEGORZ ŚLIŻEWSKI

\section{Polowanie na orly. Wstępny etap rozpracowania lotników byłych Polskich Sił Powietrznych przez Urząd Bezpieczeństwa w ramach operacji „Mewa” (1948-1949)}

Nowy podział politycznych wpływów po zakończeniu II wojny światowej sprawił, że Polska znalazła się pod kuratelą Związku Sowieckiego. W efekcie na terenie Rzeczypospolitej wprowadzono sprawdzone metody, których celem była eliminacja osób zagrażających nowej władzy. Jedną z grup społecznych, którą dotknęły działania represyjne nowej władzy, byli oficerowie i żołnierze Polskich Sił Zbrojnych (PSZ) powracający do kraju po zakończeniu działań wojennych. Temat ten od jakiegoś czasu jest sukcesywnie prezentowany $\mathrm{w}$ polskiej historiografii ${ }^{1}$, ale brak $\mathrm{w}$ nim szerszego spojrzenia na kwestie związane z repatriacją i dalszymi losami polskich lotników. W przeciwieństwie np. do Marynarki Wojennej²

\footnotetext{
$1 \quad$ Politycznie obcy! Żołnierze Wojska Polskiego w zainteresowaniu komunistycznego aparatu represji i propagandy w latach 1944-1956, red. B. Polak, P. Skubisz, Szczecin 2011; J. Wróbel, Na rozdrożu historii, Łódź 2009; Wojsko w Polsce „Ludowej”. Studia i materiały IPN, red. R. Klementowski et al., Wrocław 2011; S. Artymowski, Od tęsknoty do werbunku. Szkic o przebiegu repatriacji żolnierzy PSZ na Zachodzie do Polski w latach 1945-1948, „Studia Podlaskie" 2010, t. 18, s. 197-219; Polska pod reżimem komunistycznym. Sprawozdanie z sytuacji z kraju (1944-1949), wstęp i oprac. J. Mysiakowska-Muszyńska, W. J. Muszyński, Warszawa 2015; Aparat bezpieczeństwa $w$ Polsce w latach 1954-1956. Taktyka, strategia, metody, wyb. i oprac. G. Majchrzak, A. Paczkowski, Warszawa 2011.

2 Na przykład w październiku 2001 r. w Gdyni odbyła się konferencja poświęcona stalinowskim represjom wobec Marynarki Wojennej, pokłosiem której było wydanie dwa lata później książki pod red. Igora Hałagidy System represji stalinowskich w Polsce 19441956. Represje $w$ marynarce wojennej. Nie zabrakło też wystaw poświęconych zbrodniom
} 
(MW) Polskie Siły Powietrzne (PSP) były traktowane w sposób marginalny ${ }^{3}$.

Opracowanie niniejsze jest próbą przedstawienia początków rozpracowania operacyjnego Urzędu Bezpieczeństwa (UB) skierowanego przeciwko powracającym do kraju lotnikom. W związku z tym, że w literaturze wspomnieniowej lotników PSP brak jest wzmianek na temat inwigilacji, artykuł został oparty na dokumentach z Instytutu Pamięci Narodowej (IPN). Za końcową cezurę niniejszego opracowania autorzy przyjęli datę wprowadzenia $\mathrm{w}$ życie nowych metod prowadzenia i dokumentowania rozpracowania lotników byłych Polskich Sił Powietrznych. Dzięki temu płk Julian Konar, Naczelnik II Wydziału w I Departamencie Ministerstwa Bezpieczeństwa Publicznego (MBP) mógł zapanować nad chaosem sprawozdawczym urzędów terenowych biorących udział w „Mewie” i zintensyfikować rozpracowanie ${ }^{4}$.

Pierwszą wzmianką o zainteresowaniu służb komunistycznych lotnikami jest pismo Wojewódzkiego Urzędu Bezpieczeństwa Publicznego (WUBP) w Poznaniu. 4 stycznia 1948 r. Naczelnik Wydziału I wystąpił do Naczelnika Wydziału II Departamentu I z prośbą o przekazanie materiałów dotyczących działalności na terenie Wielkiej Brytanii czterech lotników (Tadeusza Piltza, Bernarda Buchwalda, Władysława Żegoty-Rzegocińskiego i Tadeusza Szymańskiego), którzy wrócili do krajus. Byli oni związani z Aeroklubem Poznańskim i podejrzewano ich o prowadzenie działalności szpiegowskiej. Jak wyglądały te podejrzenia, doskonale ilustrują materiały zebrane przez Terenową Komisję Weryfikacyjną nr 9, która we wrześniu

popełnionym na marynarzach; zob. np. „Zbrodnie komunistyczne w Marynarce Wojennej w okresie stalinowskim" (otwarta w grudniu 2017 r. na ul. Świętojańskiej w Gdyni była też prezentowana w styczniu 2018 r. w budynku Sejmu RP).

K. A. Tochman, Z ziemi obcej do Polski. Losy żołnierzy Polskich sił Zbrojnych, którzy powrócili do kraju po II wojnie światowej, t. 1, Zwierzyniec - Rzeszów - Londyn 2006; idem, Z ziemi obcej do Polski. Losy żołnierzy Polskich sił Zbrojnych, którzy powrócili do kraju po II wojnie światowej, t. 2, Krzeszowice 2009; idem, Gen. Tadeusz Góra - z RAF-u do komunistycznej bezpieki, „Zeszyty Historyczne” 2013, t. 12: Si vis pacem, para bellum: bezpieczeństwo i polityka Polski, s. 955-966; G. Sojda, G. Śliżewski, Mjr pil. Karol Pniak - pilot akrobacyjny Trójki Bajana, uczestnik Bitwy o Anglię, pilot Polskiego Zespołu Myśliwskiego w Afryce, dowódca 308 Dywizjonu Myśliwskiego Krakowskiego, Warszawa 2015; W. Matusiak, Powojenne losy elity polskiego lotnictwa, „Biuletyn Instytutu Pamięci Narodowej” 2011, nr 3, s. 86-96; G. Sojda, Porucznika pil. Zdzisława Radomskiego, dzieje niezwykłe..., „Przegląd Historyczno-Wojskowy" 2016, nr 2-3 (256-257), s. 373-389.

4 Archiwum Instytutu Pamięci Narodowej (dalej: AIPN), Ministerstwo Spraw Wewnętrznych w Warszawie (dalej: MSW), BU 01355/1, Krypt. „Mewa”, Pismo Naczelnika Wydziału II Departamentu I, ppłk. Juliana Konara z 4 II 1950 r., b.m., k. 2-3.

5 AIPN, MSW, BU 00231/1, Żołnierze i oficerowie RAF, t. 16, Pismo Naczelnika Wydziału I WUBP w Poznaniu do Naczelnika Wydziału II Departamentu I Ministerstwa Bezpieczeństwa Publicznego w Warszawie z 4 I 1948 r. (L.dz. BC 360/48), k. 23. 
1948 r. przyglądała się stosunkom panującym w aeroklubie ${ }^{6}$. Już na wstępie stwierdzono: „Komisja w związku z pracami weryfikacyjnymi stwierdza, że istnieją b. poważne poszlaki odnośnie istnienia na terenie aeroklubu wrogiej zorganizowanej grupy, której członkowie są w większości studentami z Akademii Handlowej i Uniwersytetu Poznańskiego. Najbardziej podejrzani zgłosili się do weryfikacji $\mathrm{w}$ dodatkowym terminie i dopiero po powiadomieniu kierownictwa Aeroklubu, że niezgłaszających się do weryfikacji Komisja uważać będzie za podejrzanych i wyciągnie $\mathrm{z}$ tego odpowiednie wnioski"'. Na podstawie przeprowadzonych rozmów za specjalnie podejrzanych uznano Władysława Walendowskiego, Władysława Żegotę-Rzegocińskiego, Tadeusza Piltza, Bernarda Buchwalda, Tadeusza Szymańskiego, inspektora Jana Czarneckiego, kierownika Wojewódzkiego Oddziału Lotnictwa Cywilnego, Mariana Matuszewskiego, Jana Przepiórkowskiego, Bohdana Sobolewskiego i Eugenię Topolnicką (tylko pierwsza piątka była związana w czasie wojny z PSP), a wielu członków aeroklubu zostało z niego usuniętych. Zarzucano im m.in. wrogość klasową i wrogość do ustroju, praktykujący katolicyzm, niejasne źródła utrzymania, chęć wydostania się za granicę, a części studentów ukrywanie przeszłości okupacyjnej. Jednocześnie w przypadku pozytywnie zweryfikowanych zalecono, by „Pewne jednostki czy nawet całe grupy działające na terenie aeroklubu winny być pod ciągłą obserwacją i przez właściwe władze rozpracowane, ze względu na to, że w Poznaniu znajduje się punkt lotnictwa bombowego dalekiego zasięgu i ze względu na położenie Poznania na magistrali Moskwa - Warszawa - Berlin"s. Ale w tym czasie był to przypadek jednostkowy.

Sytuację zmieniło, w połowie 1948 r., aresztowanie Władysława Śliwińskiego ${ }^{9}$, który zbudował w Polsce sieć wywiadowczą kierowaną przez byłych

6 AIPN, MSW, BU 00231/1, Materiały dotyczące podejrzanych o wrogą działalność na terenie aeroklubu poznańskiego zebrane przez Terenową Komisję Weryfikacyjną nr 9 w składzie: przewodniczący - mjr Czubowicz, członkowie - kpt. Klonowski Stefan, ob. Semerfeld Henryk D.O.K.P, b.d., b.m., k. 24-38.

$7 \quad$ Ibidem, $\mathrm{k} 24$.

$8 \quad$ Ibidem, k. 28.

9 Władysław Śliwiński (ur. 3 IV 1922 w Wilnie - zm. 15 II 1951) por. pil., syn Antoniego i Katarzyny z domu Mączyńskiej. Maturę zdał w gimnazjum Towarzystwa Szkoły Ziemi Mazowieckiej w 1939 r. Brał udział w obronie Warszawy jako ochotnik w 41 Pułku Piechoty. Absolwent kursu podchorążych w Szkole Podchorążych Piechoty i Kawalerii Zmotoryzowanej. W Polskich Siłach Powietrznych służył w: 306 Dywizjonie Myśliwskim (DM), 303 DM, 302 DM, 316 DM, 309 DM. Wojnę zakończył w stopniu porucznika. Został odznaczony Krzyżem Srebrnym Orderu Wojennego Virtuti Militari (VM), trzykrotnie Krzyżem Walecznych (KW). Przed powrotem do kraju został zwerbowany przez ppłk. Leona Bortnowskiego do zbudowania sieci informacyjnej pracującej dla polskiego wywiadu. Do Polski wrócił 22 VII 1947 r. Aresztowany 4 VI 1948 r. przez funkcjonariuszy UBP; zob. Instytut Polski i Muzeum im. gen. Sikorskiego (dalej: IPiMS), Akta Polskich Sił Powietrznych na Zachodzie 
pracowników Oddziału II Sztabu Głównego. Młody pilot służył podczas wojny w PSP, a przed repatriacją do Polski został zwerbowany przez ppłk. Leona Bortnowskiego ${ }^{10}$. W związku z tym, że po powrocie Władysław Śliwiński obracał się $\mathrm{w}$ środowisku byłych lotników PSP ${ }^{11}$, a jednym z jego współpracowników był kolega $\mathrm{z}$ dywizjonu $\mathrm{z}$ czasów wojny ${ }^{12}$, powstało podejrzenie, że takich sieci wywiadowczych wśród byłych lotników PSP mogło

1935-1947, LOT.A.V.1/4/XXIV, Ewidencja bojowa pilotów, s. 141; Centralne Archiwum Wojskowe Wojskowego Biura Historycznego (dalej: CAW-WBH), Kolekcja akt żołnierzy polskich powracających z Polskich Sił Zbrojnych na Zachodzie 1945-1948, II.56.6044; Zeszyt ewidencyjny, s. 1-16; MOD, Przebieg służby Śliwiński Władysław; W. Zmyślony, Tragiczny koniec por. Śliwińskiego, „Gapa” 2012, nr 1, s. 62-77; AIPN, MSW, BU 0192/406/1, Śliwiński Władysław, Plan rozpracowania punktów wyjściowych ze sprawy zlikwidowanej siatki obcego wywiadu Śliwińskiego Władysława, b.m., b.d., k. 6-16; G. Sojda, Za liniq wroga, czyli konspiracja porucznika pil. Władysława Śliwińskiego, „Kwarta” 2015, nr 3(16), s. 93-106.

10 T. Dubicki, A. Suchcitz, Oficerowie wywiadu WP i PSZ w latach 1939-1945, t. 1, Warszawa 2009, s. 64-67; W. Bagieński, Działalność wywiadowcza i kontrwywiadowcza polskich emigrantów w pierwszych latach po II wojnie światowej, „Biuletyn Informacyjny Światowego Związku Żołnierzy Armii Krajowej” 2016, nr 9, s. 113-120; A. Kozicki, Oddział Informacyjny Sztabu II Korpusu w latach 1945-1946: dalsze losy pracowników Oddziału II Sztabu Głównego, „Pamięć i Sprawiedliwość” 2008, nr 2, s. 229-242; P. Niwiński, Wywiad Okręgu Wileńskiego AK po lipcu 1944 roku [w:] W sieci. Powojenne polskie siatki wywiadowcze (AK - NIE - DSZ - WiN, PSZ) w latach 1944-1955, red. M. Bechta, Warszawa 2016, s. 116, 118; A. Kozicki, Struktury organizacyjne i formy pracy emigracyjnego wywiadu wojskowego $w$ latach 1945-1955 [w:] W sieci..., s. 418.

11 W ramach sprawy „Rampa” aresztowano dodatkowo siedmiu lotników PSP: Stanisława Skalskiego, Bolesława Jedliczkę, Zdzisława Radomskiego, Tadeusza Nowierskiego, Władysława Kamińskiego, Jana Pacholczyka i Mariana Cholewkę; zob. AIPN, MSW, BU 0192/406/1, Władysław Śliwiński, Plan rozpracowania punktów wyjściowych ze sprawy zlikwidowanej siatki obcego wywiadu Śliwińskiego Władysława, b.d., k. 17-24.

12 Pilotem tym był Bolesław Jedliczko (ur. 16 XI 1918 w Sławacinku - zm. 16 XI 2000) por. pil., syn Eugeniusza i Stefanii z Mikołajczaków. Maturę zdał w 1939 r. w Państwowym Liceum Matematyczno-Fizycznym w Białej Podlaskiej. Absolwent kursu podchorążych w Szkole Podchorążych Piechoty i Kawalerii w Auchtermuchty. W PSP służył w: 302 DM, 308 DM. Odznaczono go czterokrotnie KW. Do kraju powrócił 22 VII 1947 r.; zob. IPiMS, Akta Polskich Sił Powietrznych na Zachodzie 1935-1947, LOT.A.V.1/4/XXIV, Ewidencja bojowa pilotów, s. 182; CAW-WBH, Kolekcja akt żołnierzy polskich powracających z Polskich Sił Zbrojnych na Zachodzie 1945-1948, II.56.7332, Rejestracyjny spis żołnierzy powracających do Polski na stałe do miejsce zamieszkania z jednostek wojskowych za granicą, k. 88; B. Jedliczko, „Codzienność polska 1945-1956”, rkps w posiadaniu autorów; B. Jedliczko, „Życiorys", rkps. w posiadaniu autorów przekazany przez Dorotę Borodej; K. Kubala, Po prostu miałem szczęście, „Skrzydlata Polska” 2000, nr 12, s. 12; AIPN, MSW, BU 0259/373, Akta kontrolno-śledcze w związku z podejrzeniem o współpracę z angielskim wywiadem, przeciwko: Bolesław Jedliczko, imię ojca: Eugeniusz, ur. 18-11-1918 r., Oskarżony z art., $15 \$ 1$ i 2 w zw. $\mathrm{z}$ art. 7 i n. 
być więcej ${ }^{13}$. W takiej sytuacji rozpracowanie tego środowiska wydawało się koniecznością.

Informacja o wszczęciu rozpracowania obiektowego byłych oficerów i żołnierzy Polskich Sił Powietrznych walczących u boku Royal Air Force ${ }^{14}$, które otrzymało kryptonim „Mewa”, po raz pierwszy pojawiła się na początku 1949 r. Był to meldunek Sekcji II Wydziału I Wojewódzkiego Urzędu Bezpieczeństwa Publicznego w Poznaniu, w którym informowano warszawską centralę o rozpoczęciu działań 10 stycznia 1949 r. ${ }^{15}$ Była to kontynuacja działań poznańskich funkcjonariuszy, którzy już w 1947 r. zainteresowali się byłymi lotnikami PSP, skupionymi w Aeroklubie Poznańskim, których podejrzewano o działalność szpiegowską ${ }^{16}$.

Działania związane $\mathrm{z}$ rozpracowaniem środowiska lotników podjęły w tym czasie także inne WUBP. 3 marca 1949 r. „do rozpracowania obiektowego osób, które podczas okupacji służyły na terenie Anglii w jednostkach angielskich sił zbrojnych (RAF i Marynarka Wojenna)" przystąpili funkcjonariusze z Warszawy. Zadanie to ukryto pod kryptonimem „Lotnik”17. Kilka miesięcy później, 27 czerwca 1949 r., do rozpracowania obiektowego byłych członków PSP oraz byłych wojskowych z angielskich sił zbrojnych

13 AIPN, MSW, BU 01236/996/D, Śliwiński Władysław, Raport wicedyrektora Departamentu Śledczego do wiceministra Bezpieczeństwa Publicznego gen. Romana Romkowskiego, b.m. 21 XI 1950 r., k. 70-71.

14 PSP nie były w czasie II wojny światowej częścią składową RAF. Funkcjonariusze UBP pomijali ten fakt, uznając lotników za byłych członków Królewskich Sił Powietrznych Wielkiej Brytanii. Na podstawie porozumienia z października 1939 r. polscy lotnicy formalnie byli przyjmowani do służby na Wyspach Brytyjskich jako ochotnicza rezerwa (RAF Volunteer Reserve), bowiem brytyjskie prawo nie przewidywało innej możliwości formowania polskich jednostek na Wyspach. Jednocześnie na dowódcę polskiego lotnictwa w Wielkiej Brytanii wyznaczono generała brygady Władysława Kalkusa, a w bazie RAF Eastchurch utworzono Centrum Lotnictwa Polskiego w Anglii. Trudno obronić tezę, że en mass polscy lotnicy służyli w RAF podczas wojny; zob. G. Sojda, G. Śliżewski, P. Hodyra, Ci cholerni Polacy! Polskie Siły Powietrzne w Bitwie o Anglię, Warszawa 2012, s. 33-45.

15 AIPN, MSW, BU 00231/1, Żołnierze i oficerowie RAF, t. 16, Meldunek ppor. Stanisława Łukaszewicza, kierownika Sekcji II do Naczelnika Wydziału II Departamentu I MBP o wszczęciu rozpracowania obiektowego z 3 II 1949 r. (L. dz. BC.RO. 360/48), k. 32.

16 AIPN, MSW, BU 00231/1, Pismo Naczelnika Wydziału I WUBP w Poznaniu do Naczelnika Wydziału II Departamentu I Ministerstwa Bezpieczeństwa Publicznego w Warszawie z 4 I 1948 r. (L.dz. BC 360/48), k. 23.

17 AIPN, MSW, BU 00231/1, Żołnierze i oficerowie RAF, t. 6, Meldunek ppłk. Zbigniewa Paszkowskiego, szefa Urzędu Bezpieczeństwa Publicznego na m. st. Warszawę do Departamentu I Wydział II Ministerstwa Bezpieczeństwa Publicznego o wszczęciu rozpracowania obiektowego z 10 III 1949 r. (L.dz. 300/49/BB), k. 3. W późniejszym okresie kolejne rozpracowanie operacyjne pod nazwą „Lotnik” zostało wszczęte przez UB w celu inwigilowania oficerów lotnictwa służących wcześniej w Polskich Siłach Powietrznych na Zachodzie. 
przystąpił WUBP we Wrocławiu. Sprawa otrzymała kryptonim „Król”18. Trzy dni później rozpracowanie rozpoczął UBP w Bydgoszczy ${ }^{19}$ (początkowo nie używano kryptonimu ${ }^{20}$, dopiero 11 października $\mathrm{w}$ dokumentacji pojawia się „Mewa”), a kolejnego dnia w Krakowie ${ }^{21}$ (sprawie nadano kryptonim „Satelici”, ale został on na dokumencie wymazany i w jego miejsce wpisano „Mewa”). Przyjąć zatem można, że w celu ujednolicenia planowanej operacji na początku lipca 1949 r. przyjęto wspólny kryptonim, którym stała się nazwa używana przez poznański WUBP. Stało się to prawdopodobnie podczas odprawy w Ministerstwie Bezpieczeństwa Publicznego, w której wzięli udział kierownicy Sekcji II Wydziału I wojewódzkich urzędów bezpieczeństwa publicznego. Spotkanie to odbyło się 12 i 13 lipca 1949 r., a każdy z kierowników otrzymał polecenie nadesłania meldunków o wszczęciu rozpracowania obiektowego byłych żołnierzy PSP. Termin ich złożenia wyznaczono na 10 sierpnia $1949 \mathrm{r}^{22}$

Nazwa operacji „Mewa” od razu pojawia się w raportach o rozpoczęciu rozpracowania obiektowego w Katowicach ${ }^{23}$ (7 lipca), województwie warszawskim ${ }^{24}$ (14 lipca ${ }^{25}$ - na dokumencie widnieje kryptonim „Śmigło”, „Mewa” pojawia się w październiku 1949 r.), Kielcach $^{26}$ (15 lipca),

18 AIPN, MSW, BU 00231/1, Żołnierze i oficerowie RAF, t. 9, Raport Naczelnika Wydziału I WUBP we Wrocławiu do Naczelnika Wydziału II Dep. I MBP z 1 VII 1949 r. o wszczęciu rozpracowania obiektowego (L.dz. AD3558/49), k. 15-16.

19 AIPN, MSW, BU 00231/1, Żołnierze i oficerowie RAF, t. 17, Raport mjr. Mikołaja Krupskiego, szefa WUBP w Bydgoszczy do Naczelnika Wydziału II Dep. I MBP o wszczęciu rozpracowania obiektowego z 30 VI 1949 r. (L. dz. 4165/49), k. 13.

20 W piśmie przewodnim raportu czytamy: „Jednocześnie prosimy o powiadomienie, czy kryptonim odnośnie założonego rozpracowania obiektowego zostanie nadesłany nam przez Was, czy też możemy sami nadać"; zob. ibidem, k. 15.

${ }^{21}$ AIPN, MSW, BU 00231/1, Żołnierze i oficerowie RAF, t. 19, Raport zastępcy szefa WUBP w Krakowie do Departamentu I Wydział II MBP o wszczęciu rozpracowania obiektowego z 15 VII 1949 r., k. 19.

22 AIPN, MSW, BU 00231/1, Żołnierze i oficerowie RAF, t. 10, Pismo ppłk. Juliana Konara do Naczelnika Wydziału I Wojewódzkiego Urzędu Bezpieczeństwa Publicznego w Kielcach z 30 VIII 1949 r., k. 16.

23 AIPN, MSW, BU 00231/1, Żołnierze i oficerowie RAF, t. 11, Meldunek Naczelnika Wydziału I WUBP w Katowicach do Naczelnika Wydziału II Departamentu I MBP z 9 VII 1949 r. (AF.3981/SII/49), k. 5.

24 AIPN, MSW, BU 00231/1, Żołnierze i oficerowie RAF, t. 5, Meldunek Naczelnika Wydziału I WUBP w Warszawie do Naczelnika Wydziału II Departamentu I MBP o wszczęciu rozpracowania obiektowego z 14 VII 1949 r. (L.dz. OC-D.R.-3/49), k. 18.

25 Data umowna, gdyż nie podano, kiedy rozpoczęto operację, dlatego przyjęto datę dokumentu.

26 AIPN, MSW, BU 00231/1, Żołnierze i oficerowie RAF, t. 10, Meldunek Naczelnika Wydziału II WUBP w Kielcach kpt. Kazimierza Mozala do Naczelnika Wydziału II 
Łodzi $^{27}$ (25 lipca - na dokumencie skreślono kryptonim „Pilot”, wpisując na jego miejsce „Mewa”, Białymstoku ${ }^{28}$ i Gdańsku ${ }^{29}$ (1 sierpnia), Olsztynie ${ }^{30}$ (5 sierpnia), Rzeszowie ${ }^{31}$ (26 sierpnia), Lublinie ${ }^{32}$ (15 września) i Szczeci$n^{3}{ }^{33}$ (10 października). Operacja opatrzona kryptonimem „Mewa” pojawia się jeszcze rok później w trzech innych wojewódzkich urzędach bezpieczeństwa publicznego - w Opolu ${ }^{34}$ (30 września 1950 r.), Koszalinie ${ }^{35}$ (27 grudnia) i Zielonej Górze ${ }^{36}$ (15 stycznia 1951 r.). Późne rozpoczęcie działań $\mathrm{w}$ trzech ostatnich ośrodkach można wytłumaczyć faktem zmian na mapie administracyjnej kraju wprowadzonych 6 lipca 1950 r. - pojawiły się na niej trzy nowe województwa.

Wydaje się zatem, że zanim doszło do ukierunkowanej i systematycznej inwigilacji przybyłych z Wielkiej Brytanii lotników, w kilku wojewódzkich

Departamentu I MBP o wszczęciu rozpracowania obiektowego z 1 VIII 1949 r. (L.dz. Wb2482/49), k. 14.

27 AIPN, MSW, BU 00231/1, Żołnierze i oficerowie RAF, t. 8, Raport Naczelnika Wydziału I WUBP w Łodzi kpt. Stefan Gajewskiego do Wydziału II Departamentu I MBP z 25 VIII 1949 r. o wszczęciu rozpracowania obiektowego (L.dz. K.B. 2335/49), k. 11.

28 AIPN, MSW, BU 00231/1, Żołnierze i oficerowie RAF, t. 13, Raport szefa WUBP w Białymstoku mjr. Teodora Mikusia do Naczelnika Wydziału II Departamentu I MBP o wszczęciu rozpracowania obiektowego z 5 VIII 1949 r. (L.dz. 3853/49), k. 10.

29 AIPN, MSW, BU 00231/1, Żołnierze i oficerowie RAF, t. 14, Meldunek płk. Józefa Jurkowskiego, szefa WUBP w Gdańsku do Naczelnika Wydziału II Departamentu I MBP o wszczęciu rozpracowania obiektowego z 14 VIII 1949 r. (L.dz. AB-3156/49), k. 11.

30 AIPN, MSW, BU 00231/1, Żołnierze i oficerowie RAF, t. 15, Meldunek ppłk. Henryka Palki, szefa WUBP w Olsztynie do Naczelnika Wydziału II Departamentu I MBP o wszczęciu rozpracowania obiektowego z 19 VIII 1949 r. (L.dz. DS.-3079/49), k. 10.

31 AIPN, MSW, BU 00231/1, Żołnierze i oficerowie RAF, t. 12, Raport Naczelnika Wydziału I WUBP w Rzeszowie do Naczelnika Wydziału II Departamentu I MBP o wszczęciu rozpracowania obiektowego z 31 VIII 1949 r. (L.dz. RO 2/a), k. 14.

32 AIPN, MSW, BU 00231/1, Żołnierze i oficerowie RAF, t. 20, Meldunek ppłk. Artura Jastrzębskiego, szefa WUBP w Lublinie do MBP (Dep. I Wydz. II) o wszczęciu rozpracowania obiektowego kr. „Mewa” z 29 IX 1949 r.

33 AIPN, MSW, BU 00231/1, Żołnierze i oficerowie RAF, t. 18, Meldunek szefa WUBP w Szczecinie do Naczelnika Wydziału II Departamentu I MBP o wszczęciu rozpracowania obiektowego z 19 X 1949 r. (L.dz. R.O.-6/49), k. 14.

34 AIPN, MSW, BU 00231/1, Żołnierze i oficerowie RAF, t. 21, Meldunek por. Tomasza Olejniczaka, kierownika Sekcji II Wydziału I WUBP w Opolu do Wydziału II Departamentu I MBP o wszczęciu rozpracowania obiektowego „Mewa” z 18 X 1950 r., k. 9.

35 AIPN, MSW, BU 00231/1, Żołnierze i oficerowie RAF, t. 22, Meldunek Naczelnika Wydziału WUBP w Koszalinie do Naczelnika Wydziału II Departamentu I MBP o wszczęciu rozpracowania obiektowego z 20 I 1951 r. (L.dz. T-B-167/51), k. 7.

36 AIPN, MSW, BU 00231/1, Żołnierze i oficerowie RAF, t. 23, Raport Naczelnika Wydziału WUBP w Zielonej Górze do Naczelnika Wydziału II Departamentu I MBP o wszczęciu rozpracowania obiektowego z 29 I 1951 r. (L.dz. B.F. 149/51), k. 8. 
urzędach bezpieczeństwa publicznego doszło do oddolnej inicjatywy w tej sprawie. Tak było w Poznaniu, Warszawie, Wrocławiu i prawdopodobnie w Bydgoszczy, gdzie najwcześniej zainteresowano się przybyłymi do kraju żołnierzami PSP. To prawdopodobnie te działania dały impuls ppłk. Julianowi Konarowi ${ }^{37}$, naczelnikowi II Wydziału w I Departamencie ${ }^{38}$, by zająć się sprawą globalnie. Jednocześnie można stwierdzić, że ppłk Konar starał się ujednolicić sposób przekazywania materiałów do kierowanego przez niego departamentu, co widać $\mathrm{w}$ notatce służbowej jednego z podległych mu w MBP referentów, który 23 listopada $1949 \mathrm{r}$. przeprowadził rozmowę telefoniczną z kierownikiem Sekcji II Wydziału I WUBP w Rzeszowie w sprawie „Mewy” i „Wyspy”39. Czytamy w niej m.in. „Jednocześnie poinformował mnie, że odnośnie punktów wytyczonych w planie przedsięwzięcia nie wykonał ani jednego" ${ }^{40}$.

$\mathrm{Z}$ analizy zachowanych dokumentów wynika, że od momentu zawiązania sprawy ukrytej pod kryptonimem „Mewa” powracających do Polski lotników zaczęto oplatać gęstą siecią informatorów, którzy śledzili ich poczynania. Informatorów tych można podzielić na trzy grupy. Pierwszą stanowili koledzy i koleżanki z pracy, którzy przekazywali informacje o zachowaniu podczas wykonywania obowiązków służbowych. W skład drugiej wchodzili sąsiedzi i znajomi, których zadaniem było gromadzenie wiadomości o życiu prywatnym. Ostatnią stanowili natomiast lotnicy służący w PSP, którzy z różnych przyczyn zdecydowali się na współpracę z funkcjonariuszami UBP.

W Wielkopolsce rozpoznanie środowiska lotniczego zaowocowało w styczniu 1949 r. wszczęciem rozpracowania byłych członków PSP, których

37 Właśc. Julian Kohn (ur. 28 IX 1920 w Warszawie - zm. 11 XI 2006), pochodzenia żydowskiego. W 1941 r. wstąpił do tzw. Armii Andersa, z którą udał się do Buzułuku, następnie na przeszkolenie do Saratowa, skąd został odesłany do macierzystej jednostki. Wraz z kilkoma innymi osobami zażądał zwolnienia i przekazania Armii Czerwonej. Po zwolnieniu z Armii Andersa pracował w kołchozie jako robotnik, następnie jako traktorzysta. W 1943 r. rozpoczął studia na Wydziale Prawa ewakuowanego do Saratowa Uniwersytetu Leningradzkiego. W maju 1943 r. przerwał naukę w związku z wezwaniem przez Związek Patriotów Polskich do Moskwy i skierowaniem do formującej się 1 Dywizji Piechoty im. Tadeusza Kościuszki (brał udział w walkach pod Lenino). Następnie został skierowany do batalionu szturmowego, skąd w 1944 r. drogą powietrzną udał się do kraju jako dowódca grupy dywersyjnej. Po wykonaniu zleconych zadań oddał się do dyspozycji dowództwa Armii Ludowej (AL) i Komitetu Centralnego (KC) Polskiej Partii Robotniczej (PPR). W lipcu 1944 r. został skierowany rozkazem Sztabu Partyzanckiego w ZSRR do dyspozycji ministra Stanisława Radkiewicza. Początkowo pracował w Lublinie, a od 4 IV 1945 r. w Ministerstwie Bezpieczeństwa Publicznego w Warszawie. Naczelnikiem II Wydziału w I Departamencie został 15 VII 1946 r.

38 Departament I zajmował się kontrwywiadem, a wchodzący w jego skład Wydział II zwalczaniem szpiegostwa brytyjskiego.

39 „Wyspa” dotyczyła inwigilacji obywateli brytyjskich przebywających w Polsce.

40 AIPN, MSW, BU 00231/1, Żołnierze i oficerowie RAF, t. 12, Notatka służbowa z 23 XI 1949 r., b.m., k. 19. 
podejrzewano o współpracę z obcym wywiadem, które otrzymało kryptonim „Mewa”. Ustalono, że na terenie województwa poznańskiego przebywa 10 oficerów, 25 podoficerów i 4 żołnierzy związanych w czasie II wojny światowej z PSP. Najwięcej, bo 11, mieszkało w powiecie gnieźnieńskim, nieco mniej w powiecie ostrowskim (10), Poznaniu (6) i okolicach Chodzieży (5). Poza tym dwóch znajdowało się w Śremie, a po jednym w Jarocinie, Koninie, Obornikach, Szamotułach i Zielonej Górze. Zaznaczyć przy tym należy, że do listy dopisano także żołnierzy Samodzielnej Brygady Spadochronowej ${ }^{41}$.

Funkcjonariusze działali $\mathrm{w}$ dwóch obszarach: starali się dowiedzieć jak najwięcej o organizacji Polskich Sił Powietrznych w Wielkiej Brytanii oraz - co było dla nich bardziej istotne - zebrać materiały na temat działalności byłych lotników PSP ze szczególnym uwzględnieniem ich kontaktów z placówkami dyplomatycznymi państw zachodnich. W pierwszym przypadku użyteczny okazał się informator używający pseudonimu „12”, który w przeszłości był pilotem jednego z polskich dywizjonów myśliwskich w Wielkiej Brytanii. W drugim przypadku szczególne zainteresowanie wzbudzili George Scott, brytyjski wicekonsul w Katowicach, który kontaktował się z Władysławem Walendowskim oraz Joseph Kinal, pracownik ambasady USA, z którym spotykał się Marian Matuszewski. Ustalenia agenturalne związane z działalnością Matuszewskiego doprowadziły funkcjonariuszy bezpieczeństwa publicznego do wniosku, że tworzy on siatkę szpiegowską. W związku z tym w kwietniu 1949 r. sprawa została przekazana do Wydziału V Departamentu I MBP, który zajmował się zwalczaniem szpiegostwa amerykańskiego i tym samym została wyłączona $\mathrm{z}$ „Mewy”42.

Tymczasem George Scott był wielu lotnikom dobrze znany - przed wojną mieszkał we Lwowie, a w czasie działań wojennych był tłumaczem w polskich jednostkach lotniczych. Jego syn, Elgin, urodził się w Polsce i w 1945 r. był pilotem 315 „Dęblińskiego” Dywizjonu Myśliwskiego. Można odnieść wrażenie, że Brytyjczycy zaangażowali go w katowickim konsulacie w celach wywiadowczych - na Śląsku znajdowało się sporo przesiedlonych mieszkańców Kresów Wschodnich, wśród których mogli być jego przedwojenni znajomi. Także kontakty $\mathrm{z}$ lotnikami PSP mogły być przydatne w zdobywaniu informacji.

Poszukiwania kolejnych lotników wciąż trwały - w lipcu 1949 r. na listach WUBP w Poznaniu pojawiły się nowe nazwiska ${ }^{43}$. W ramach operacji

41 AIPN, MSW, BU 00231/1, Żołnierze i oficerowie RAF, t. 16, Meldunek o wszczęciu rozpracowania obiektowego z 3 II 1949 r., k. 32.

42 AIPN, MSW, BU 00231/1, Pismo ppłk. Konara, Naczelnika Wydz. II Dep. I MBP do Naczelnika Wydziału V Dep. I MBP z 19 IV 1949 r., k. 44.

43 AIPN, MSW, BU 00231/1, WUBP Wydział I Sekcja II, Raport nr 3 o przebiegu rozpracowania obiektowego z 30 VII 1949 r. (L.dz. BC.360/48/RO.2.), k. 57-61. 
ustalono, że w samym tylko Poznaniu przebywa ich o 64 więcej niż wykazano pierwotnie ${ }^{44}$. W innych powiatach sytuacja zmieniła się niewiele w Chodzieży jeden z figurantów przeprowadził się do woj. wrocławskiego (zostało czterech), w Gnieźnie wykryto trzech nowych lotników (razem 14), w powiecie poznańskim 12 (razem $18^{45}$ ), w Ostrowie Wielkopolskim czterech (razem 14), w Kośnie siedmiu (razem 7), w Nowym Tomyślu czterech (razem 4), w Zielonej Górze dwóch (razem 3), w Żninie, Gostyniu i Mogilnie po dwóch (razem po 2), w Szamotułach jednego (razem 2), w Kępnie, Strzelcach Krajeńskich, Pile i Kościanie ${ }^{46}$ po jednym (razem po 1), w Kaliszu wciąż przebywało 12, w Wągrowcu trzech, w Śremie dwóch, w Jarocinie, Obornikach, Lesznie i Koninie - po jednym, a w Czarnkowie, Kole, Krotoszynie, Międzychodzie, Międzyrzeczu, Rawiczu, Skwierzynie, Słubicach, Środzie Wielkopolskiej, Gubinie, Sulęcinie, Turku, Wolsztynie, Wrześni i Gorzowie Wielkopolskim nie znaleziono żadnego byłego członka Polskich Sił Powietrznych. W dokumencie podano, że "na terenie woj. poznańskiego ustalono 173 byłych żołnierzy i oficerów RAF”47. Liczba ta nie zgadza się z wyliczeniami autorów, którzy po zsumowaniu wszystkich podanych w raporcie liczb, doliczyli się ich $157^{48}$.

Tym razem poznański Urząd Bezpieczeństwa Publicznego zainteresował się kontaktami angielskiego konsula Josepha Waltersa z lotnikami służącymi w przeszłości w RAF. Wiadomość o nich przekazali informatorzy o pseudonimach „Bokser” i „12”, którzy wspomnieli o spotkaniu Brytyjczyka z Wacławem Nyczem, byłym pilotem 318 Dywizjonu Myśliwsko-Rozpoznawczego, zatrudnionym w Międzynarodowych Targach Poznańskich. Planowano również $w$ poszczególnych powiatowych urzędach bezpieczeństwa publicznego spośród lotników PSP wytypować kandydatów na werbunek.

Kolejny raport dotyczący „Mewy” został przygotowany pod koniec października $1949 \mathrm{r}^{49}{ }^{49}$ Wynikało $\mathrm{z}$ niego, że $\mathrm{z}$ powodu choroby informatora „12” nie udało się ustalić kontaktów Wacława Nycza z brytyjskim konsulem

44 Po dodaniu wspomnianych 64 lotników i 6 z pierwszego opracowania autorom Raportu wyszło 72 figurantów; zob. ibidem, k. 62.

45 Podawane dane nie są precyzyjne. W dokumencie z początku 1949 r. brak jakichkolwiek lotników mieszkających w powiecie.

46 Powiatowy Urząd Bezpieczeństwa Publicznego podał, że ustalonych zostało pięciu figurantów, ale trzech z nich było marynarzami, a jeden żołnierzem piechoty; zob. AIPN, MSW, BU 00231/1, Żołnierze i oficerowie RAF, t. 16, WUBP Wydział I Sekcja II, Poznań, Raport nr 3 o przebiegu rozpracowania z 30 VII 1949 r., k. 39.

47 Ibidem, k. 62.

48 Ibidem.

49 AIPN, MSW, BU 00231/1, Raport nr 4 o przebiegu rozpracowania obiektowego z 22 X 1949 r. (L.dz. BC.360/48/RO.2.), k. 65-68. 
Waltersem. Jednocześnie podano aktualny stan akcji werbunkowej (dwóch nowych informatorów w Kaliszu, jeden w powiecie poznańskim i jeden w Gnieźnie) oraz liczebności lotników PSP w woj. poznańskim ${ }^{50}$. W sumie do tego czasu zwerbowano dziewięciu informatorów - wszyscy byli byłymi żołnierzami lub oficerami PSP ${ }^{51}$, ustalono także 145 figurantów $^{52}$.

Mimo dużego nakładu środków i czasu na rozpracowanie środowiska byłych lotników PSP nic nie wskazywało na ich działania skierowane przeciwko nowej władzy: „W okresie sprawozdawczym z punktu widzenia kontrwywiadu przejawów wrogiej działalności po bazie byłych oficerów i żołnierzy RAF-u nie stwierdzono, nie ujawniono żadnych momentów wskazujących na bliższe kontaktowanie się między sobą czy też szerzenie wrogiej propagandy. Doniesienia otrzymane w tym okresie od posiadanej agentury zawierają treść informacyjną o poszczególnych figurantach spraw nowo ujawnionych lub dotychczas danych po linii innych Wydziałów. Z pobieżnej analizy wynika, że większość figurantów nie zajmuje żadnych stanowisk w instytucjach państwowych posiadających znaczenie gospodarcze, a przeważnie są zatrudnieni w swoim zawodzie jako ślusarze, szoferzy, kupcy czy też pomocnicze siły biurowe" ${ }^{53}$. Jednocześnie kierownictwo WUBP wyprzedzało ewentualny atak z Warszawy, wyjaśniając: „Na niedostateczną ocenę działalności obiektu z punktu widzenia kontrwywiadu składa się brak dostatecznej ilości dobrej agentury w tym środowisku, która nie mogła być zwerbowana z powodu nie ukończenia całkowitego prześwietlenia wszystkich figurantów sprawy"54.

3 marca 1949 r. rozpracowanie byłych lotników PSP rozpoczęto w Warszawie (kryptonim „Lotnik”). Decyzję tę uzasadniano: „Przystąpiono do rozpracowania obiektowego osób, które podczas okupacji służyły na terenie Anglii w jednostkach angielskich sił zbrojnych (RAF i Marynarka Wojenna). Wśród nich mogą znajdować się ludzie zwerbowani przez I.S. ${ }^{55}$, a następnie repatriowani wraz z innymi Polakami do kraju w celach szpiegowskich. Sekcja II do tej pory zarejestrowała 170 osób, które służyły w jednostkach

\footnotetext{
50 Poznań - 90, Chodzież - 1 (okazało się, że dwóch nie jest lotnikami, jeden wyjechał do Poznania), Gniezno - 15, Gorzów Wielkopolski - 4, Kępno - 2, Krosno - 0 (wykazywani wcześniej okazali się nie mieć nic wspólnego z lotnictwem), Leszno - 4, Międzyrzecz - 2, Nowy Tomyśl - 7, powiat poznański - 15, Sulęcin - 1, Piła - 2, Zielona Góra - 2; ibidem.

51 Ibidem, k. 67.

52 Autorzy dokumentu podają liczbę 189 figurantów (ibidem, s. 83), z wyliczeń autorów tekstu wynika natomiast, że było ich 145 .

53 Ibidem, k. 66-67.

$54 \quad$ Ibidem, k. 64.

55 Intelligence Service - właściwie Secret Intelligence Service (SIS), brytyjski wywiad zagraniczny.
} 
angielskich lub pracowały w obiektach angielskiego przemysłu wojennego. Obecnie zamieszkują $\mathrm{w} \mathrm{W}$-wie i pracują $\mathrm{w}$ instytucjach państwowych. Ludzie ci pracują na 50 obiektach, bądź grupowo, bądź pojedynczo - przeważnie na kierowniczych stanowiskach. Największe zgrupowanie tych ludzi obecnie jest w PLL «LOT» i M.P.iH ${ }^{56}$. Wśród tych ludzi znajdują się osoby, które podczas okupacji były szkolone w Anglii w specjalnych szkołach dywersyjnych, a następnie zrzucani do walki z okupantem. Były wypadki, że niektórzy po wyzwoleniu nie zaprzestali swej działalności i w dalszym ciągu pracowali na korzyść angielskiego wywiadu"57.

UBP dla miasta Warszawy miał do dyspozycji jedynie dwóch informatorów (w Polskich Liniach Lotniczych „LOT” oraz Ministerstwie Przemysłu i Handlu), musiał więc swoją siatkę skutecznie rozwinąć. Do podstawowych zadań, które przed sobą postawili funkcjonariusze, należało ustalenie liczby mieszkających w stolicy byłych żołnierzy PSP oraz prześwietlenie ich pod kątem współpracy z obcym wywiadem (brano pod uwagę także miejsce zatrudnienia figurantów). Szczególne zainteresowanie wzbudzali ci, którzy mieli dostęp do spraw będących tajemnicą państwową - mieli być albo otaczani agenturą, albo sami werbowani. Jednocześnie uwagę skierowano na osoby, które pracowały razem z przybyłymi z Zachodu żołnierzami, a które planowano zwerbować do tworzenia sieci informacyjnej. W pierwszej kolejności nacisk nałożono na miejsca, gdzie lotników było najwięcej, czyli na PLL „LOT” oraz Ministerstwo Przemysłu i Handlu.

Kolejny raport, z czerwca 1949 r., potwierdził dotychczasowe ustalenia ${ }^{58}$. Została do niego dołączona lista 172 osób, które znalazły się w kręgu zainteresowań funkcjonariuszy stołecznego UBP w ramach „Lotnika”. Według niej 110 spośród nich związanych było z lotnictwem, 53 to byli pracownicy przemysłu wojennego Wielkiej Brytanii, a pozostali to marynarze. Były to ustalenia dotyczące lewobrzeżnej Warszawy - danych z Pragi jeszcze nie posiadano. Nie oznacza to jednak, że lista była wolna od błędów, np. przypisany do personelu lotniczego Stanisław Łącki był w rzeczywistości rezerwistą broni pancernej. W wykazie wojennych przydziałów znajdują się m.in. żołnierze 1 Samodzielnej Brygady Spadochronowej (13), Centrum Wyszkolenia Saperów (5) czy 1 Dywizji Pancernej (8). Do listy należy zatem podejść $\mathrm{z}$ rezerwą.

\footnotetext{
56 Ministerstwo Przemysłu i Handlu.

57 AIPN, MSW, BU 00231/1, Żołnierze i oficerowie RAF, t. 6, Meldunek ppłk. ZbigniewaPaszkowskiego, szefa Urzędu Bezpieczeństwa Publicznego na m. st. Warszawę do Departamentu I Wydziału II Ministerstwa Bezpieczeństwa Publicznego o wszczęciu rozpracowania obiektowego z 10 III 1949 r. (L.dz. 300/49/BB), Warszawa 17 VI 1949 r., k. 3.
}

58 AIPN, MSW, BU 00231/1, Raport do MBP Departamentu I Wydziału II o przebiegu rozpracowania obiektowego z 17 VI 1949 r. (L.dz. 300/49/BB), k. 22-28. 
Najwięcej byłych lotników PSP zatrudnionych było w PLL „LOT” (14, z czego pięciu zdążono już stamtąd zwolnić), Ministerstwie Przemysłu i Handlu (siedmiu) oraz w firmach prywatnych (sześciu). W szkolnictwie pracę znalazło siedmiu (trzech w Szkole Wawelberga, dwóch na Politechnice Warszawskiej i po jednym na Uniwersytecie Warszawskim i w Liceum Lotniczym). Spora grupa byłych lotników zatrudniona była w najwyższych organach władzy: trzech w Ministerstwie Odbudowy, a po jednym w Ministerstwie Skarbu, Ministerstwie Rolnictwa, Ministerstwie Komunikacji i Ministerstwie Spraw Zagranicznych. Poza tym przedstawiciele lotnictwa pracowali m.in. w Izbie Skarbowej, Sądzie Okręgowym, PKO, Państwowym Banku Rolnym, Państwowym Przedsiębiorstwie Budowlanym, Państwowych Zakładach i Warsztatach Samochodowych, RSW Prasa czy Centrali Łożysk, a jeden z nich był np. dozorcą domu. Jednocześnie poinformowano centralę, że rozpoczęto współpracę z VIII Wydziałem IV Departamentu MBP, który zajmował się rozpracowywaniem PLL „LOT”, w których zatrudnionych było wielu lotników mających w swojej przeszłości służbę w PSP. Było to o tyle istotne, że stołeczny UBP, mimo iż nie miał na to żadnych konkretnych dowodów, widział poważne zagrożenia ze strony byłych członków Polskich Sił Powietrznych, w tym także zatrudnionych wówczas w PLL „LOT”.

W analizie i ocenie działalności lotników zawartej we wspomnianym raporcie czytamy: „W dotychczasowym rozpracowaniu nie uzyskano konkretnych materiałów świadczących o wrogiej działalności wśród tego elementu. Jednak wg niepotwierdzonych danych, duża ilość figurantów wstąpiła po przybyciu do Polski w szeregi PPS i PPR, obecnie znalazła się w PZPR. Informacje pochodzą od członków partii.

Zachowanie się tych ludzi wg powyższych informacji jest wrogie, żyją wspomnieniami z Anglii, a do partii wstąpili koniunkturalnie. Zważywszy jednak, że element ten w 90\% posiada przeszłość wrogą do demokracji, co wynika z zamieszczonych charakterystyk, oraz to, że podczas pobytu w Anglii służył w jej siłach zbrojnych, stykając się z I.S., które posiadają w tych szeregach swoich agentów, jest to podatna baza dla obcego wywiadu. Biorąc zaś pod uwagę rozmieszczenie tego elementu na obiektach, zajmowane stanowiska, to zorganizowanie na tej bazie siatki lub siatek wywiadowczych jest niezwykle łatwe.

Trzeci moment wskazujący na niebezpieczeństwo wykorzystania tej bazy przez obce wywiady to fakt, że duża ilość tych ludzi zatrudnionych $\mathrm{w}$ «LOT» lata za granicę, gdzie może spotykać się z agentami obcych wywiadów.

W związku z powyższym postanowiliśmy w bieżącym okresie uaktywnić rozpracowanie do granic naszych możliwości” ${ }^{59}$.

$59 \quad$ Ibidem, k. 25. 
Aby rozeznać się w sytuacji lotników w PLL „LOT”, wykorzystano 24-letniego starszego referenta Jerzego Michalaka ze stołecznego UBP, który kolegował się z sekretarzem koła PZPR tego zakładu pracy: „Michalak porozumie się z sekretarzem i zasięgnie informacji, który z członków partii jest uczciwym PZPR-owcem, na podstawie opinii sekretarza wytypujemy trzech ludzi, z którymi można rozmawiać, poczem [sic!] poprosimy ich na konspiracyjną rozmowę, w trakcie której będziemy się starali odtworzyć strukturę, a także uzyskać informacje o ludziach, ich zachowanie się za granicą i obecnie. O sposobie przyjazdu, o rozmowach i zachowaniu się, o stosunkach poszczególnych lub grupowo do obecnej rzeczywistości i do partii. Wniesie nam to do rozpracowania oświetlenie zagadnienia i pozwoli bardziej celowo nasadzać sieć informacyjną" ${ }^{00}$.

Służyć to miało przede wszystkim podstawowemu celowi, jaki postawili sobie stołeczni funkcjonariusze bezpieczeństwa publicznego - zbudowaniu sieci informacyjnej. Ich zainteresowania obracały się w strefie ustalenia wszystkich byłych członków PSP zamieszkujących w Warszawie wraz z ustaleniem miejsca zamieszkania oraz miejsca pracy i zajmowanego stanowiska. Postanowili również rozpracować strukturę polskich jednostek przy brytyjskich Królewskich Siłach Powietrznych, stawiając sobie przy tym niewykonalne zadania, np. ustalenie ich pełnej obsady personalnej. Interesowało ich zachowanie Polaków w Wielkiej Brytanii, możliwość kontaktów z Secret Intelligence Service, a w kwestiach związanych z przybyciem do kraju - kto pierwszy przyjechał, kto kogo ściągał, kto kogo i gdzie protegował lub angażował do pracy, jak również jaki jest stosunek byłych podwładnych do byłych przełożonych, czy dalej słuchają swoich dawnych dowódców. Wytypowano także grupę 11 osób, które zamierzano zwerbować, by poznać strukturę PSP i ich obsadę personalną, a także mieć swoich ludzi w miejscach, gdzie znajdowały się skupiska lotników służących w czasie wojny w lotnictwie. Wśród nich znaleźli się m.in. byli członkowie personelu bazy w Blackpool, szkoły pilotażu w Hucknall, dywizjonów 300, 301, 302, 303 i 316, jak również 1 Samodzielnej Brygady Spadochronowej.

Wojewódzki Urząd Bezpieczeństwa we Wrocławiu rozpoczął rozpracowywanie byłych członków PSP oraz byłych wojskowych związanych w przeszłości z angielskimi siłami zbrojnymi 27 czerwca 1949 r. Naczelnik Wydziału I WUBP we Wrocławiu uzasadniał tę decyzję następująco: „Po zakończeniu działań wojennych zostali [figuranci - dop. aut.] zdemobilizowani i powrócili do Kraju w latach 46-47, osiedlając się we Wrocławiu, zajmując często stanowiska kierownicze $\mathrm{w}$ administracjach państwowych, samorządowych i w przemyśle. Większość z nich jest zatrudniona w przemyśle na kierowniczych stanowiskach. Przeważnie w działach planowania 
i działach technicznych, gdzie mają dostęp do wszelkich planów i statystyk produkcyjnych. W większości są to ludzie negatywnie ustosunkowani do PZPR, jak i do polityki Rządu. Jaskrawym faktem jest, że część b. czł. RAF dość często spotykają się z osobami narodowości angielskiej. [...] Wobec tego, że są na wysokich stanowiskach w przemyśle i instytucjach państwowych i samorządowych, gdzie obcy wywiad może ich wykorzystać do pracy szpiegowskiej i jest element podatny na werbunek przez obcy wywiad, postanowiłem założyć rozpracowanie obiektowe w celu ściślejszej obserwacji i rozpracowania ww." ${ }^{61}$

Operacja otrzymała kryptonim „Król” i zakładała ustalenie miejsca zamieszkania i pracy (plus zajmowane stanowiska i kontakty $z$ innymi pracownikami) dotychczas ustalonych 51 figurantów z Wrocławia oraz nakazanie Powiatowym Urzędom Bezpieczeństwa Publicznego (PUBP), by poczyniły podobne ustalenia w terenie. Szczegóły planowano uzyskać m.in. poprzez rozmowy z dozorcami domów (funkcjonariusze WUBP mieli podać się za pracowników Zarządu Miasta) i kierownikami referatu personalnego zakładów pracy (funkcjonariusze WUBP rozpytywać mieli jednocześnie o kilku przypadkowych pracowników, by nie było jasne, kim w rzeczywistości są zainteresowani). Zamierzano też wytypować trzech kandydatów do werbunku spośród ustalonych już byłych żołnierzy walczących na Zachodzie.

Pierwszy raport o przebiegu rozpracowania lotników PSP prowadzonego przez WUBP we Wrocławiu (z końca sierpnia 1949 r.) weryfikował dotychczasowe dane ${ }^{62}$. Na terenie miasta przebywało 30 byłych członków PSP, pozostali okazali się przedstawicielami innych rodzajów broni. Liczba ta nie zwiększyła się, ponieważ mimo monitów do PUBP, te nie przesłały informacji o zamieszkałych na ich terenie figurantach związanych $\mathrm{z}$ „Mewą”. Jednocześnie zdecydowano się dokładniej przyjrzeć dziesięciu osobom, które zatrudnione były w Państwowych Zakładach Lotniczych na Psim Polu we Wrocławiu. Cytując: „Zajmują oni kierownicze stanowiska nie tylko w działach produkcji ogólnej, ale w działach konstrukcyjnych i planowania, które z racji swej pracy stanowią biura najbardziej tajne, niedostępne nawet dla miejscowego kierownictwa, a podlegające bezpośrednio centrali w Warszawie. Biorąc pod uwagę charakter i znaczenie ww. Zakładów Lotniczych dla odbudowującego się przemysłu Polski Ludowej z jednej strony, a obsadę kierowniczą tychże Zakładów, rekrutującą się z elementu [sic!] przedwojennych - sanacyjnych oficerów przybyłych z Zachodu po ostatniej

${ }_{61}$ AIPN, MSW, BU 00231/1, Żołnierze i oficerowie RAF, t. 9, Raport Naczelnika Wydziału I WUBP we Wrocławiu do Naczelnika Wydziału II Dep. I MBP o wszczęciu rozpracowania obiektowego z 1 VII 1949 r. (L.dz. AD3558/49), k. 15.

62 AIPN, MSW, BU 00231/1, Raport nr 1 WUBP we Wrocławiu, Wydział I Sekcja II, o przebiegu rozpracowania obiektowego krypt. „Mewa” z 31 VIII 1949 r., k. 19-22. 
Wojnie Światowej (Anglia i jej Dominia), przesiąkniętych na wskroś ideałami zachodniej demokracji i ich polityki, stanowiącą podatny grunt do wykorzystania przez obcy wywiad z drugiej strony, podejrzewamy ww. grupę o działalność szpiegowską i dywersyjno-sabotażową na rzecz obcego mocarstwa, a o tem [sic!], że taka istnieje na terenie PZL, świadczy zamieszczony artykuł $\mathrm{w}$ angielskim czasopiśmie z lutego 49 r. wydawanym w języku angielskim, którego kopia znajduje się w Wydz. IV tut. Urzędu, charakteryzujący szczegółowo rozwój naszego przemysłu lotniczego z podaniem konstrukcji poszczególnych samolotów, rozmieszczenie fabryk lotniczych na terenie RP i osoby zajmujące kierownicze stanowiska w tymże przemyśle. O działalności wroga świadczy także fakt wykrycia przez Wydz. IV tut. Urzędu zaistniałego ostatnio sabotażu na terenie PZL i ekspozytury tegoż Zakładu w Lubawce pow. Kamienna-Góra woj. Wrocław, w produkcji śrub do wiązania poszczególnych części samolotów ze sobą, wykonanego tak wyrafinowanie, że obecnie napotyka się na duże trudności w ustaleniu winnych - uzasadniano tę decyzję"63.

Wojewódzki Urząd Bezpieczeństwa Publicznego w Bydgoszczy oficjalnie skupił swoją uwagę na lotnikach służących w czasie wojny w PSP 30 czerwca 1949 r. - w tym dniu do warszawskiej centrali przekazano meldunek w tej sprawie ${ }^{64}$. Swoje zainteresowanie tłumaczono następująco: „Przytłaczająca część składu osobowego tego elementu powróciła do kraju po to, by siać ferment i niezadowolenie wśród tut. społeczeństwa, by hamować odbudowę i rozwój Polski Socjalistycznej, a niektórzy z nich poszli na całkowitą współpracę z wywiadem angielskim” ${ }^{65}$. „Ogólnie biorąc pod uwagę, jakim środowiskiem jest klika andersowska i jej wrogie ustosunkowanie się do obecnej rzeczywistości w Polsce Demokracji Ludowej, należy wnioskować, iż wśród elementu składającego się z byłych członków angielskich sił zbrojnych, którzy obecnie powrócili do kraju, znajdują się też i osoby o podobnym zapatrywaniu. Większość z nich podczas pobytu swego na terenach Anglii przeszła różnego rodzaju kursy, a między innymi i wywiadowcze. Nie ulega więc kwestii, iż po powrocie swym do kraju oraz odpowiednim zaaklimatyzowaniu się, będą oni starali się nawiązywać łączność z elementami wrogo ustosunkowanymi i samym ośrodkiem Anglia. W dużym stopniu po powrocie do kraju, jak wynika $\mathrm{z}$ dotychczas posiadanych materiałów, pozajmowali oni stanowiska przeważnie $\mathrm{w}$ fabrykach oraz poszczególnych instytucjach. Pełniąc służbę swą, mogą w różnego rodzaju czy też formie

63 Ibidem, k. 19-20.

64 AIPN, MSW, BU 00231/1, Żołnierze i oficerowie RAF, t. 17, Raport mjr. Mikołaja Krupskiego, szefa WUBP w Bydgoszczy do Naczelnika Wydziału II Dep. I MBP o wszczęciu rozpracowania obiektowego z 30 VI 1949 r. (L. dz. 4165/49), k. 13.

65 Ibidem, k. 13. 
dokonywać aktów sabotażu, hamując przebieg odbudowy i rozwoju gospodarczego Polski, a zarazem przekazywać wiadomości odnośnie jakości czy też ilości produkowanych materiałów"66.

$\mathrm{Na}$ terenie woj. pomorskiego funkcjonariusze bezpieczeństwa publicznego zlokalizowali 46 lotników walczących na Zachodzie, w tym 11 oficerów. Byli oni rozlokowani na całym terenie podległym WUBP, a największa, licząca 14 osób, grupa mieszkała w Bydgoszczy. Poza tym byli członkowie PSP zatrzymali się w powiatach w Wąbrzeźnie, Chełmnie, Inowrocławiu (po sześciu), Świeciu, Rypinie (po trzech), Toruniu (dwóch) oraz Włocławku, Nowym Mieście, Chojnicach, Grudziądzu i Aleksandrowie Kujawskim (po jednym) ${ }^{67}$. Tradycyjnie postawiono sobie zadanie zwerbowania kliku spośród nich.

Ponieważ po tym meldunku do Ministerstwa Bezpieczeństwa Publicznego nie wpływały żadne materiały, 11 października 1949 r. ppłk Konar wystosował do WUBP w Bydgoszczy ponaglające pismo, w którym prosił o przesłanie meldunku o przebiegu rozpracowania. Zostało ono wysłane do Warszawy 3 grudnia ${ }^{68}$. Podkreślano $\mathrm{w}$ nim, że prowadzone są intensywne działania mające rozpracować środowisko związane z PSP, choć czasami napotykano na nieprzewidziane trudności, np. w Chełmnie zwolniono z pracy w PUBP pracownika zajmującego się tą sprawą i dopiero niedawno został do niej przydzielony nowy urzędnik. Wynikało z niego również, że dzięki zwerbowanej agenturze odnaleziono w Bydgoszczy sześciu kolejnych lotników, a jednocześnie dwóch wyjechało do Warszawy i Wrocławia. Duże zainteresowanie funkcjonariuszy wzbudzał Wiktor Sydor, ale wynikało to prawdopodobnie $\mathrm{z}$ faktu, że jego znajomym z czasów wojny był nowy informator o pseudonimie „Cambrich”. Ogółem zwerbowano czterech informatorów, a piątego "przejęto z rozpracowania b. żołnierzy armii Andersa”"69. Także w Grudziądzu zlokalizowano pięciu nowych lotników i rozpoczęto ich rozpracowanie oraz werbunek. W Wąbrzeźnie „nie zdołano poprzez posiadaną agenturę oraz prowadzone wywiady zebrać mocniejszych dowodów odnośnie ich wrogiej działalności oraz kontaktów"70. W Inowrocławiu napotkano trudności z werbunkiem, bo większość lotników była członkami

66 Ibidem, k. 22-23.

${ }^{67} \mathrm{Z}$ przedstawionej listy wynika, że w woj. pomorskim było 45, a nie - jak podało w raporcie kierownictwo WUBP w Bydgoszczy - 46 lotników PSP. Podobnie jak w poprzednich przypadkach do przygotowanych zestawień przez funkcjonariuszy bezpieczeństwa publicznego należy podchodzić z dużą dozą sceptycyzmu, gdyż nie wszyscy z wymienionych służyli w czasie wojny w polskim lotnictwie.

68 AIPN, MSW, BU 00231/1, Żołnierze i oficerowie RAF, t. 17, Raport nr 1 mjr. Mikołaja Krupskiego, szefa WUBP w Bydgoszczy do Naczelnika Wydziału II Dep. I MBP o przebiegu rozpracowania obiektowego, k. 29.

69 Ibidem, k. 34.

70 Ibidem, k. 36. 
PZPR, którzy w tej kwestii byli poza zainteresowaniami UBP. Jednocześnie wytypowano trzy osoby, które „swym zachowaniem wykazują do pewnego stopnia wrogie oblicze w stosunku do obecnej rzeczywistości, jednakowoż konkretnej działalności nie przejawiają"71.

Mimo że w żadnym $\mathrm{z}$ raportów z PUBP nie znaleziono dowodów wywrotowej działalności, nie przeszkodziło to autorowi opracowania skonstatować we wnioskach: „Analizując osiągnięte materiały w ramach obiektowego rozpracowania, należy stwierdzić, że środowisko objęte rozpracowaniem obiektowym pod krypt. «Mewa» jest wrogie obecnej rzeczywistości. Jest to element wyczekujący oraz bardzo nieprzychylnie ustosunkowany do zmian społecznych, jakie zaistniały w Polsce.

$\mathrm{Z}$ uwagi na to, że środowisko to nie jest należycie opanowane siecią agencyjną przez poszczególne PUBP, w związku z tym nie zdołano ujawnić wrogiej działalności poszczególnych osób rozpracowania względnie ich środowisk. Jednakowoż niemniej mając na uwadze ich nastawienie polityczne, pobyt w czasie wojny oraz częściowo po wyzwoleniu za granicą, ich wrogi stosunek do obecnej rzeczywistości, należy wnioskować, iż kontynuują oni wrogą pracę, względnie są zdolni przystąpić do czynienia takowej w każdym czasie. Słuchają oni radia brytyjskiego i rozsiewają wrogą propagandę godzącą w interesy Państwa Polskiego, jak też utrzymują kontakty z innym wrogim elementem"72.

Jednocześnie przy pomocy agentury poszczególnych PUBP przystąpiono do opracowania kandydatów do werbunku spośród byłych członków PSP i położono nacisk, by do werbunku doszło jak najszybciej.

Wojewódzki Urząd Bezpieczeństwa Publicznego w Krakowie inwigilację polskich lotników walczących na Zachodzie rozpoczął 1 lipca 1949 r. Uzasadniano tę decyzję następująco: „Po zakończeniu działań wojennych rok 1947-1948 był [czasem - dop. aut.] masowej repatriacji ww. elementu do kraju i jak stwierdzono na podstawie danych agencyjnych oraz innych materiałów półoficjalnych, względnie śledczych, to osoby te są o nastawieniu proangielskim, poglądach sanacyjnych i w większości wrogo ustosunkowani do obecnej rzeczywistości - a co za tym idzie, mogli być niewątpliwie przed swoim przyjazdem do kraju zaangażowani do pracy wywiadowczej dla angielskiego wywiadu IS”73. „Na podstawie doświadczeń z pracy w Aparacie Bezpieczeństwa ustalono, że byli członkowie Brytyjskich Sił Zbrojnych - lądowych, lotniczych (RAF) i morskich, którzy wrócili z Anglii do kraju, stanowią element, który w większości jest nastawienia proangielskiego oraz

\footnotetext{
$71 \quad$ Ibidem, k. 38.

72 Ibidem, k. 41.

73 AIPN, MSW, BU 00231/1, Żołnierze i oficerowie RAF, t. 19, Raport zastępcy szefa WUBP w Krakowie do Departamentu I Wydział II MBP o wszczęciu rozpracowania obiektowego z 15 VII 1949 r., k. 19.
} 
wrogo ustosunkowany do Polski Ludowej i niewątpliwie niektórzy z nich są powiązani z ośrodkami wywiadowczymi, działając na szkodę Demokratycznego Państwa Polskiego"74.

Jednocześnie krakowskie kierownictwo postawiło przed sobą sześć zadań, które miały być wprowadzone w życie w stosunku do osób, które znalazły się w kręgu zainteresowań „Mewy”. Chodziło o przeprowadzenie wszechstronnych wywiadów w miejscu zamieszkania i pracy, zainteresowanie figurantami agentury znajdującej się w miejscu zatrudnienia, wytypowanie najlepszych kandydatów do werbunku i z tej grupy zwerbowanie czterech informatorów, uzyskanie z powiatowych UBP szczegółowych charakterystyk zamieszkałych na danym terenie osób znajdujących się w kręgu zainteresowania „Mewy”, a w przypadku werbunku w terenie (w miejscach, w których znajdowały się większe skupiska byłych lotników) osobistej pomocy miał udzielać referent prowadzący sprawę. Poza tym nakazano agentowi o kryptonimie „Sto” nawiązać kontakt $\mathrm{z}$ dwoma lotnikami, których znał jeszcze z czasów przedwojennych - Eustachym Ekielskim i Tadeuszem Walką ${ }^{75}$.

Pierwsze sprawozdanie ze związanych z „Mewą” działań prowadzonych przez krakowski WUBP jest datowane na 24 października $1949 \mathrm{r}^{76}$ Wynika z niego, że w kręgu zainteresowań bezpieki znalazł się Bolesław Halski ${ }^{77}$, który w swoim mieszkaniu jeden z pokoi zamienił na gościnny. Przyjmował tam przylatujący do Krakowa personel PLL „LOT”, w tym byłych członków PSP. Zwerbowano także nowego informatora o kryptonimie „Stanisław”. $\mathrm{W}$ analizie przeprowadzonych działań przyznano, że dotychczasowe rozpracowania nie były prowadzone zbyt aktywnie (tłumaczono się nawałem pracy przy innych prowadzonych sprawach). Jednocześnie $w$ dokumencie zapisano: „Materiały uzyskane drogą agencyjną i przez wywiady wskazują, że niektórzy członkowie RAF-u po powrocie do Kraju prowadzą spokojny tryb życia w swym gronie rodzinnym, a niektórzy zaś jak wskazują materiały są wrogo ustosunkowani do obecnej rzeczywistości o proangielskim usposobieniu, utrzymują kontakty z Anglią, otrzymują stamtąd prasę od swoich przyjaciół i rozpowszechniają wiadomości z powyższej prasy"78.

\footnotetext{
$74 \quad$ Ibidem, k. 25.

75 Ibidem, k. 25-28.

76 AIPN, MSW, BU 00231/1, Żołnierze i oficerowie RAF, t. 19, Raport do Ministerstwa Bezpieczeństwa Publicznego Departament I Wydział II o przebiegu obiektowego rozpracowania sprawy pod krypt. „Mewa” nr RO-2/CB/49 z 24 X 1949 r., k. 33-34.

77 Halski był członkiem Polskich Sił Powietrznych w Wielkiej Brytanii, meteorolog w stopniu podoficerskim.
}

78 AIPN, MSW, BU 00231/1, Żołnierze i oficerowie RAF, t. 19, Raport do Ministerstwa Bezpieczeństwa Publicznego Departament I Wydział II o przebiegu obiektowego rozpracowania sprawy pod krypt. „Mewa” nr RO-2/CB/49 z 24 X 1949 r., k. 34. 
Jednocześnie krakowski WUBP postawił przed sobą pięć nowych zadań, wśród których znalazło się m.in. zlokalizowanie do 20 grudnia 1949 r. byłego personelu PSP oraz ustalenie charakteru działalności Bolesława Halskiego, a do 31 grudnia 1949 r. zwerbowanie trzech informatorów spośród byłych członków PSP ${ }^{79}$.

Krakowski raport został nieprzychylnie przyjęty przez ppłk. Konara. W piśmie do naczelnika Wydziału I czytamy: „Meldunek ten nie obrazuje stanu wykonania planowanych przez Was przedsięwzięć zawartych w raporcie o wszczęciu rozpracowania z dnia 12 VII 1949 r., poza tym nakreślony [plan] działania nie zawiera konkretnych przedsięwzięć operacyjnych związanych z powyższym rozpracowaniem. [...] Należy zmierzać do rozbudowy proporcjonalnej ilości agentury, która umożliwi opracowanie interesującego nas elementu oraz sygnalizować będzie o ewentualnych przejawach wrogiej działalności. [...] Nawiązując do przesyłanych przez Was meldunków o stanie rozpracowań będących pod Waszą kontrolą, komunikuję, iż nie obrazują one $\mathrm{w}$ dostatecznej mierze przebiegu rozpracowań, jak i pracy $\mathrm{z}$ agenturą, stawianych jej zadań, właściwego wykorzystania oraz słuszności przeprowadzonych werbunków. W związku z powyższym proszę zleci [sic!], omawiać obszernie powyższe zagadnienia, podawając [sic!] treści ważniejszych doniesień i stawianie odnośnie ich dalsze działania. Przy typowaniu kandydatury na werbunek wskazać należy cel mającego nastąpić werbunku, przygotowanie się do niego i podstawę, na jakiej zostanie on przeprowadzony. Pozatem należy podać stan wykonania planowanych przedsięwzięć, dokonanych werbunków, uwzględniając werbunki nieudane i ich przyczyny oraz w planie operacyjnym przedsięwzięć omówić kierunek dalszego rozpracowania"80. Podpułkownik Konar dał też kilka szczegółowych poleceń dotyczących sposobu rozpracowania kilku osób wspomnianych w raporcie z 24 października.

7 lipca 1949 r. do realizacji rozpracowania operacyjnego (RO) „Mewa” przystąpił Wojewódzki Urząd Bezpieczeństwa Publicznego w Katowicach ${ }^{81}$. Naczelnik Wydziału I WUBP Katowice raportował: „W toku drugiej wojny światowej pewna część polskich sił zbrojnych przedostaje się różnymi drogami do Wielkiej Brytanii, gdzie pewna część oficerów i żołnierzy zostaje wcielonych w skład brytyjskich sił zbrojnych. Przebywając w tych jednost-

\footnotetext{
$79 \quad$ Ibidem, k. 24.

80 AIPN, MSW, BU 00231/1, Żołnierze i oficerowie RAF, t. 19, Do Wojewódzkiego Urzędu Bezpieczeństwa Publicznego w Krakowie. Naczelnik Wydziału I-go. BA-388/49, b.d., k. 35-36.

81 AIPN, MSW, BU 00231/1, Żołnierze i oficerowie RAF, t. 11, Meldunek Naczelnika Wydziału I WUBP w Katowicach do Naczelnika Wydziału II Departamentu I MBP z 9 VII 1949 r. (AF.3981/SII/49), k. 14-16.
} 
kach, byli wystawieni na systematyczne działania propagandy imperialistycznej, wrogiej postępowi społecznemu. Zważywszy jeszcze na okoliczności, że poważny odsetek żołnierzy, a szczególnie oficerowie to zdecydowani zwolennicy polskiej odmiany faszyzmu, sanacji, otrzymamy pełny obraz ich politycznego oblicza. Po zakończeniu działań wojennych, część ww. elementu powróciła do Kraju w ramach akcji repatriacyjnej, powodowana bądź to uczciwym patriotyzmem, czy też względami rodzinnymi, bądź też chęcią wykonania zleconych jej zadań wywiadowczych. Na razie zebrane materiały informacyjne o ww. środowisku są bardzo szczupłe, ze względu na to, że środowiskiem tym do chwili obecnej nie interesowaliśmy się" ${ }^{22}$.

W dokumencie podano krótkie charakterystyki sześciu żołnierzy służących w czasie wojny w Wielkiej Brytanii (pięciu lotników i jednego oficera 1 SBS). Przyznano jednocześnie, że do ich rozpracowania nie użyto żadnej agentury, co nie przeszkodziło w postawieniu twierdzenia, że „Nie ulega wątpliwości, że wywiad anglosaski nie omieszkał wielu z tych ludzi wykorzystać dla celów wywiadowczych, których z pewnością wykorzystuje na terenie Polski. W związku z powyższym należy ww. wziąć w aktywne rozpracowanie celem wykrycia i zdemaskowania tych, którzy współpracują z obcymi wywiadami"»3.

Mimo tej deklaracji do końca roku do warszawskiej centrali nie spłynął żaden raport potwierdzający jakąkolwiek związaną z "Mewą” aktywność agenturalną. Było to sprzeczne z planem przedsięwzięć operacyjnych, które zamierzano zakończyć do końca listopada 1949 r. Zakładano, bowiem ustalenie w Rejonowych Komisjach Uzupełnień (RKU) nazwisk byłych członków brytyjskich sił zbrojnych, ich liczby i rozmieszczenia, a także poprzez agenturę, luźne kontakty, również drogą wywiadów dane personalne i charakterystyki osób związanych z „Mewą”. To drugie zadanie miało zaowocować wytypowaniem najbardziej niebezpiecznych figurantów, którzy zostaliby poddani aktywnemu rozpracowaniu ${ }^{84}$.

Na 14 lipca 1949 r. jest datowane pismo z Wojewódzkiego Urzędu Bezpieczeństwa Publicznego w Warszawie, informujące o wszczęciu operacji „Mewa” na terenach przyległych do stolicy ${ }^{85}$. Oprócz charakterystyki 16 lotników, którzy znaleźli się w orbicie zainteresowań funkcjonariuszy bezpieki, w dokumencie znajduje się analiza i ocena posiadanych przez WUBP materiałów. „Element składający się z byłych Rafowców jest podatnym do

\footnotetext{
$82 \quad$ Ibidem, k. 14.

83 Ibidem, k. 15.

$84 \quad$ Ibidem, k. 16.

85 AIPN, MSW, BU 00231/1, Żołnierze i oficerowie RAF, t. 5, Meldunek Naczelnika Wydziału I WUBP w Warszawie do Naczelnika Wydziału II Departamentu I MBP o wszczęciu rozpracowania obiektowego z 14 VII 1949 r. (L.dz. OC-D.R.-3/49), k. 18-22.
} 
wykorzystania przez wywiad angielski - ponieważ mentalność tych osób jest proangielska i są wrogo ustosunkowani do obecnej rzeczywistości, co tym samym daje możność ich wykorzystania, a tym bardziej że osoby te pracując na dość poważnych obiektach, którymi interesuje się wywiad angielski - są obiektem naszego zainteresowania z punktu widzenia kontrwywiadu. Jesteśmy w posiadaniu materiałów, że Attaché Lotniczy Amb. Ang., na którego jest założone rozpracowanie pod krypt. «Tur», interesując się bardzo byłymi Rafowcami, okazując chęć nawiązania stosunków (kontaktów) towarzyskich, pod którymi mogą kryć się inne intencje. W tym celu planuje urządzić przyjęcie, na które chce zaprosić sporą liczbę osób (pracowników) z personelu PLL «LOT», którzy w przeważającej liczbie są to byli Rafowcy. W związku z powyższym postanawiamy przystąpić aktywnie do rozpracowania byłych Rafowców, ponieważ ludzie ci mogą stanowić bazę werbunkową dla obcego wywiadu, dla potwierdzenia służyć może fakt o likwidacji siatki szpiegowskiej przez Dep. I rezydenta Śliwińskiego, jak i innych Rafowców"86.

Do wykonania tego zadania warszawski WUBP miał do dyspozycji jednego agenta oraz trzech informatorów. Poza tym planowano przeprowadzić wywiady o figurantach i przeprowadzić szersze ich rozpoznanie przez powiatowe UBP, a także poddać baczniejszej obserwacji pracowników PLL „LOT” i PZL Okęcie, ze szczególnym uwzględnieniem osób znajdujących się w sferze zainteresowań brytyjskiego attaché. Po ustaleniu, które osoby utrzymują ze sobą najbliższy kontakt, miano wytypować kandydatów na werbunek.

Jednocześnie kierownictwo warszawskiego WUBP zastrzegało, że nie posiada zbyt wielu materiałów potrzebnych do przeprowadzenia "Mewy” i na razie działania skupiać się będą na ustaleniu i lokalizacji lotników w terenie. Działania te były chyba jednak mało produktywne, bo 11 października ppłk Konar monitował o przesłanie mu konkretnych informacji. $\mathrm{Na}$ ponaglenie to w ogóle nie było odpowiedzi, więc naczelnik II Wydziału I Departamentu MBP ponowił swoje żądania 9 grudnia.

Prace nad „Mewą” rozpoczęły się w WUBP w Kielcach 15 lipca 1949 r. ${ }^{87}$ $\mathrm{W}$ uzasadnieniu podjęcia rozpracowania podano niemal identyczne powody

\footnotetext{
86 AIPN, MSW, BU 00231/1, Żołnierze i oficerowie RAF, t. 5, Meldunek Naczelnika Wydziału I WUBP w Warszawie do Naczelnika Wydziału II Departamentu I MBP o wszczęciu rozpracowania obiektowego z 14 VII 1949 r. (L.dz. OC-D.R.-3/49), k. 19-20.

87 AIPN, MSW, BU 00231/1, Żołnierze i oficerowie RAF, t. 10, Meldunek kpt. Kazimierza Mozala, Naczelnika Wydziału II WUBP w Kielcach do Naczelnika Wydziału II Departamentu I MBP (L.dz. Wb-2482/49) o wszczęciu rozpracowania obiektowego z 1 VIII 1949 r., k. $17-18$.
} 
jak w przypadku innych urzędów, czyli służba w obcym wojsku, praca dla obcych wywiadów czy też niechęć do obecnego ustroju ${ }^{88}$.

Według ustaleń WUBP w Kielcach na terenie województwa przebywało wówczas pięciu lotników służących w RAF - czterech w Kielcach i jeden w Ostrowcu. Dwóch z nich zostało zwerbowanych przez Sekcję VI Wydziału I ${ }^{89}$ WUBP w Kielcach. W związku z tym planowano przejąć ich na kontakt w zamian za dwóch informatorów pracujących na rzecz II Sekcji. Poza tym do 30 września miały zostać rozpracowane środowiska, w których przebywali figuranci oraz wytypowany kandydat na werbunek.

Mimo wyznaczenia terminów nie zostały one dotrzymane - w piśmie z 30 sierpnia 1949 r. ppłk Konar dopominał się raportu w sprawie „Mewy” ${ }^{\text {. }}$.

W Łodzi rozpracowanie rozpoczęto 25 lipca $^{91}$. Łódzki WUBP posiadał wiedzę o 11 lotnikach służących w czasie wojny w PSP oraz 40 kolejnych, o których wiedziano jedynie, że zamieszkują na terenie podlegającym urzędowi. Przeprowadzona analiza zebranych danych pozwoliła stwierdzić, że większość $\mathrm{z}$ figurantów pracuje $\mathrm{w}$ instytucjach państwowych (Łódzkie Zakłady Lotnicze Doświadczalne, PLL „LOT”, Aeroklub Łódzki) i w państwowym przemyśle, gdzie zajmowali odpowiedzialne i kierownicze stanowiska. Tym samym byli narażeni na zainteresowanie obcego wywiadu ${ }^{92}$.

Do dyspozycji było trzech informatorów („Jan”, „Ted” i „Mila”) związanych ze środowiskiem lotników służących w PSP. Jeden z nich już na pierwszym spotkaniu poinformował, że $\mathrm{u}$ angielskiego wicekonsula $\mathrm{w}$ Łodzi w prawie każdym tygodniu zbierały się Angielki, które wyszły za mąż za Polaków. Szczególnym zainteresowaniem łódzkiego UBP cieszył się mjr Konstanty Sabiłło, którego rozpracowaniem zajęto się w pierwszej kolejności. Poza tym postawiono sobie zadanie zebrania bliższych danych dotyczących lotników służących w czasie wojny w Wielkiej Brytanii, wytypowania wywodzących się ze środowiska RAF kandydatów na werbunek, a także

\section{$88 \quad$ Ibidem, k. 17.}

89 Sekcja VI prowadziła prace przeciwko działalności antypaństwowej osób i organizacji stawiających sobie za zadanie zdezorganizowanie transportu kolejowego, samochodowego, drogowego, rzecznego, morskiego i powietrznego oraz łączności: poczta, telefony, telegraf, radio - drogą organizacji sabotażu, szkodnictwa i dywersji, jak również przeciwko osobom pracującym w transporcie i łączności, a zajmującym się szpiegostwem na rzecz obcego mocarstwa.

90 AIPN, MSW, BU 00231/1, Żołnierze i oficerowie RAF, t. 10, Pismo ppłk. Konara do Naczelnika Wydziału I Wojewódzkiego Urzędu Bezpieczeństwa Publicznego w Kielcach z 30 VIII 1949 r., k. 16.

91 AIPN, MSW, BU 00231/1, Żołnierze i oficerowie RAF, t. 8, Raport kpt. Stefana Gajewskiego, Naczelnika Wydziału I WUBP w Łodzi do Wydziału II Departamentu I MBP o wszczęciu rozpracowania obiektowego z 25 VIII 1949 r. (L.dz. K.B. 2335/49), k. 11-18.

92 Ibidem, k. 14. 
opracowanie schematu graficznego, na którym zaznaczone byłoby miejsce zamieszkania osób, którymi interesowanie się w ramach „Mewy” ${ }^{93}$.

Jednocześnie zainteresowanie łódzkich funkcjonariuszy wzbudził Czesław Perek, który w Wielkiej Brytanii służył w oddziale obsługującym balony zaporowe. Skupił na sobie uwage po tym, jak lokalni funkcjonariusze dowiedzieli się, że jego adres miał Jan Kaim, członek Stronnictwa Narodowego (SN), który został aresztowany po nielegalnym przekroczeniu granicy i próbach organizacji SN na terenie Polski. Szczegółów informacji o lotniku nie udało się jednak zdobyć, gdyż jak pisał ppłk Konar: „Jednocześnie komunikujemy, że nie jesteśmy w stanie pogłębić powyższych materiałów, z uwagi na to, że Kaim Jan na podstawie wyroku Wojskowego Sądu Rejonowego w Warszawie został skazany na karę śmierci i wyrok został wykonany" ${ }^{94}$.

Podobnie jak w innych WUBP, także w Łodzi nie spieszono się z rozpracowaniem polskich lotników. Świadczy o tym ponaglające pismo ppłk. Konara z 11 października 1949 r. ${ }^{95} \mathrm{~W}$ odpowiedzi kpt. Gajewski, naczelnik Wydziału I WUBP w Łodzi, wystosował pismo do Ministerstwa Bezpieczeństwa Publicznego z prośbą o „przesłanie nam ankiet byłych członków RAF-u, którzy po przyjeździe z Anglii do Polski przechodzili przez Punkt Etapowy w Dziedzicach i zgłosili swój przydział do Łodzi lub woj. łódzkiego. Ankiety powyższe znajdują się w Dep. II MBP przekazane przez WUBP w Katowicach po likwidacji Punktu Etapowego w Dziedzicach. Powyższe jest nam potrzebne w celu wykorzystania do sprawy RO «Mewa»" ${ }^{\text {. }}$. Żaden meldunek do ppłk. Konara jednak nie dotarł, a WUBP w Łodzi otrzymał w grudniu 1949 r. kolejne ponaglające pismo ${ }^{97}$.

1 sierpnia pracę nad „Mewą" rozpoczęto w Białymstoku' ${ }^{98}$. Autor dokumentu podkreślał, że wielu lotników 5 Pułku Lotniczego w Lidzie zostało internowanych na Łotwie, skąd po roku trafiło do ZSRR. Zostało tam też wysiedlonych wiele osób, które prowadziły tzw. wrogą działalność. Trafili oni ostatecznie do armii dowodzonej przez gen. Władysława Andersa i po jej wyjściu ze Związku

\footnotetext{
93 Ibidem, k. 15.
}

94 AIPN, MSW, BU 00231/1, Pismo ppłk. Juliana Konara do Naczelnika Wydziału I Wojewódzkiego Urzędu Bezpieczeństwa Publicznego w Łodzi z 5 XI 1949 r. (BA-444/49), k. 22.

95 AIPN, MSW, BU 00231/1, Pismo ppłk. Juliana Konara do Naczelnika Wydziału I Wojewódzkiego Urzędu Bezpieczeństwa Publicznego w Łodzi z 11 X 1949 r. (BA-444/49), k. 18.

96 AIPN, MSW, BU 00231/1, Pismo kpt. Stefana Gajewskiego, Naczelnika Wydz. I WUBP w Łodzi do Naczel. Wydz. II Dep. I Min. Bezp. Publ. w Warszawie z 20 X 1949 r. (L.dz. K.B.2335/49), k. 23.

97 AIPN, MSW, BU 00231/1, Pismo ppłk. Juliana Konara do Naczelnika Wydziału I Wojewódzkiego Urzędu Bezpieczeństwa Publicznego w Łodzi z 9 XII 1949 r. (BA-444/49), k. 25.

98 AIPN, MSW, BU 00231/1, Żołnierze i oficerowie RAF, t. 13, Raport mjr. Teodora Mikusia, szefa WUBP w Białymstoku do Naczelnika Wydziału II Departamentu I MBP o wszczęciu rozpracowania obiektowego z 5 VIII 1949 r. (L.dz. 3853/49), k. 10. 
Sowieckiego zostali przesunięci do Wielkiej Brytanii, by uzupełnić stany polskiego lotnictwa. Po wojnie część z nich wróciła do Polski. WUBP ustalił, że na Białostocczyźnie znajduje się 15 osób związanych z PSP: trzech oficerów, dziesięciu podoficerów i dwóch szeregowych. Dziewięciu z nich mieszkało w Białymstoku, pozostali w terenie ${ }^{99}$. Funkcjonariusze zakładali, że lotnicy specjalnie zatrudniali się $\mathrm{w}$ istotnych dla państwa instytucjach państwowych, by prowadzić działalność szpiegowską ${ }^{100}$. Uważali, że mieli ku temu uzasadnione podstawy, bo u zatrudnionego w Centrali Rolniczej Związku Samopomoc Chłopska Aleksandra Kuleszy znaleziono odpisy różnych materiałów, a także kwestionariusze działaczy PPR ${ }^{101}$. Funkcjonariusze mieli do dyspozycji dwóch informatorów („Torowski”, „Woźny”), z których jeden miał bliskie kontakty ze środowiskiem lotniczym. Przymierzano się także, poza zwykłym w takich przypadkach zbieraniem materiałów i ustalania kontaktów, do kilku werbunków oraz prowokacji1 ${ }^{102}$.

4 października białostoccy funkcjonariusze przygotowali pierwszy raport w sprawie „Mewy”, który wysłano do Ministerstwa Bezpieczeństwa Publicznego w Warszawie. Podano w nim, że ustalono 21 figurantów, zwerbowano trzech informatorów („Hannibal”, „Kamiński” i „Spokojny”) i jednocześnie wysunięto daleko idące wnioski: „Na podstawie danych zewnętrznej obserwacji i drogą agencyjną ustalono, że figuranci rozpracowania «Mewa» zam. w B[iałym]stoku kontaktują się wszyscy między sobą, przy czym są wrogo nastawieni do obecnej rzeczywistości. Ich działalność, kontakty, jak odpisywanie materiałów poufnych, kontakt $\mathrm{z}$ oficerem WP oraz kontakty innych figurantów z osobami stojącymi na wysokich stanowiskach nasuwa podejrzenie uprawiania przez ten element roboty szpiegowskiej"103.

17 października białostoccy funkcjonariusze przesłali kolejny dokument do warszawskiej centrali - tym razem była to charakterystyka 11 osób, które znalazły się w sferze zainteresowań „Mewy”. Dwie z nich nie służyły w czasie wojny w Polskich Siłach Powietrznych ${ }^{104} .5$ listopada był gotowy

\footnotetext{
$99 \quad$ Ibidem, k. 10.

100 Ibidem, k. 13.

101 Aleksander Kulesza nie służył w czasie II wojny światowej w Polskich Siłach Powietrznych na Zachodzie.

102 AIPN, MSW, BU 00231/1, Żołnierze i oficerowie RAF, t. 13, Raport mjr. Teodora Mikusia, szefa WUBP w Białymstoku do Naczelnika Wydziału II Departamentu I MBP o wszczęciu rozpracowania obiektowego z 5 VIII 1949 r. (L.dz. 3853/49), k. 22.

103 AIPN, MSW, BU 00231/1, Pismo Naczelnika Wydziału I WUBP w Białymstoku do Naczelnika Wydziału II Dep. I MBP w Warszawie z 4 X 1949 r. (3853/RO-„,Mewa”), k. 16.

104 AIPN, MSW, BU 00231/1, Pismo Naczelnika Wydziału I UBP w Białymstoku do Naczelnika Wydz. II Departamentu I MBP w Warszawie z 17 X 1949 r. wraz z 11 charakterystykami figurantów (L.dz. CB-3853/49), k. 27-37.
} 
raport $\mathrm{nr} 2$ o przebiegu rozpracowania, który skierowano do MBP. Skupiono się w nim na rozpracowaniu byłych członków PSP, które zaowocowało stwierdzeniem, że są oni ze sobą powiązani i mają wrogi stosunek do obecnej rzeczywistości. Natomiast kontakty z ludźmi na wyższych stanowiskach pozwoliły na wysnucie wniosku, iż istnieje podejrzenie o szpiegostwo (przy jednoczesnej konstatacji braku ustalenia konkretów takiej działalności, co tłumaczono brakiem odpowiedniej agentury). Jednocześnie do rozpracowania włączono dwóch zwerbowanych agentów: „Metalowca” i „Pokrzywdzonego". Obaj nie służyli wcześniej w lotnictwie. Zakładano, że w najbliższym czasie zwerbowane zostaną kolejne osoby ${ }^{105}$.

9 stycznia 1950 r. przygotowano kolejny raport dotyczący „Mewy”. Wynika z niego, że korespondencja lotników znalazła się pod kontrolą funkcjonariuszy UBP. Spore zainteresowanie wzbudził Stanisław Gryko, który będąc szoferem w Poczcie Polskiej, miał powiedzieć swojemu naczelnikowi, że w chwili opuszczania Anglii kontaktował się z nim brytyjski wywiad, by zaproponować współpracę. Jednocześnie fakt ten utwierdził funkcjonariuszy UBP, że byli lotnicy PSP są wykorzystywani przez Secret Intelligence Service. Wciąż trwał werbunek, m.in. funkcjonariusze z Białegostoku udali się do PUBP w Grajewie, gdzie pomogli wytypować i zwerbować informatora „Wolność", który był właścicielem sklepu spożywczego. Oprócz podobnych ludzi niezwiązanych $\mathrm{z}$ lotnictwem, a jedynie znajdujących się w pobliżu lotników (drugim z nowych informatorów był „Brakarz”, sołtys wsi) wyjątkiem był informator "Jaskółka”, którego na początku stycznia $1950 \mathrm{r}$. zwerbowano w Białymstoku. Był to młody oficer, który w czasie wojny służył w PSP i wrócił do kraju z żoną Angielką. Do współpracy został zmuszony na podstawie tzw. kompromitujących materiałów, tego jakich niestety nie wiemy. Zgodnie z przedstawionymi w dokumencie wytycznymi w najbliższym czasie zamierzano skupić się na werbunku informatorów oraz zbieraniu informacji o lotnikach. Ułatwić to miały wizyty we wszystkich powiatach dwóch specjalnie do tego celu wyznaczonych funkcjonariuszy WUBP ${ }^{106}$.

Podobnie jak w Białymstoku, 1 sierpnia 1949 r. rozpoczęto w Gdańsku prace nad „Mewą"107. Według wstępnych ustaleń gdańskich funkcjonariuszy na terenie województwa znajdowało się 49 lotników, z czego 27 oficerów,

105 AIPN, MSW, BU 00231/1, WUBP w Białymstoku Wydział I Sekcja II Raport nr 2 o przebiegu rozpracowania obiektowego z 5 XI 1949 r., k. 30-32.

106 AIPN, MSW, BU 00231/1, WUBP w Białymstoku Wydział I Sekcja II Raport nr 3 o przebiegu rozpracowania obiektowego z 9 I 1950 r., k. 34-36.

107 AIPN, MSW, BU 00231/1, Żołnierze i oficerowie RAF, t. 14, Meldunek płk. Józefa Jurkowskiego, szefa WUBP w Gdańsku do Naczelnika Wydziału II Departamentu I MBP o wszczęciu rozpracowania obiektowego z 14 VIII 1949 r. (L.dz. AB-3156/49), k. 11. 
20 podoficerów i 2 szeregowców. 31 z nich mieszkało w Trójmieście, co w raporcie oceniono jednoznacznie: „Większa część figurantów obiektu osiedliła się $\mathrm{w}$ naszych miastach portowych oraz pobliskich miejscowościach im przyległych. Teren ten z jego urządzeniami portowymi, stoczniami oraz zapleczem portowym stanowi obiekt zainteresowania dla obcego wywiadu. W związku z tym nasuwa się podejrzenie, że element ten osiedlił się celowo na terenie ww. miast celem ewentualnego kontynuowania pracy dywersyjno-wywiadowczej” 108 . Obawy „ubeków” budziło to, że środowisko byłych lotników PSP może się stać elementem podatnym na działania obcych służb wywiadowczych. W rozpracowaniu nie stwierdzono takich przypadków, ale żywe kontakty z zagranicą mogłyby być zarzewiem takiego działania ${ }^{109}$.

W dokumencie przedstawiono krótkie życiorysy 13 lotników, z których spore zainteresowanie wzbudził zamieszkały w Tczewie Brunon Semmerling. Nic dziwnego - znalazły się tam informacje o jego działalności z czasów wojny. Był wówczas pilotem 315 DM, który podczas lotu bojowego w 1943 r. został zestrzelony w walce nad Francją. Udało mu się uniknąć niewoli i powrócić do Wielkiej Brytanii. Wkrótce potem znalazł się w orbicie zainteresowań brytyjskiego wywiadu i został przerzucony do Francji, gdzie rozpoczął działalność w ruchu oporu. Informacje te musiały być niezwykle istotne dla MBP - na marginesie meldunku znalazł się bowiem podkreślony dopisek: „skąd te dane? K." ${ }^{110}$.

WUBP w Gdańsku ubolewał w dokumencie, że posiada znikomą liczbę agentury, składającej się w Gdańsku z dwóch informatorów, kapitanów lotnictwa - „S.18” i „Ryszarda” (prawd. Ignacy Olszewski). Poza tym w Lęborku pomocny miał być „Śledź”, urzędnik celny mający możliwość obserwacji lotnika zatrudnionego jako kontroler rybacki w Łebie. Do tego samego celu zatrudniono informatora "Jaskółkę", rybaka posiadającego własny kuter.

Najbliższymi celami, które wyznaczono sobie w Gdańsku, było skorzystanie z zasobów powiatowych urzędów rejonowych oraz RKU i ujawnienie dotychczas nieznanych byłych członków PSP, inwigilacja korespondencji oraz sprawdzenie własnych zasobów i rozeznanie w terenie, by wykorzystać zdobyte informacje do werbunku lub rozpracowania.

Jak można się było spodziewać, UBP początkowo interesowała przede wszystkim osoba Brunona Semmerlinga ${ }^{111}$. Oprócz niego uwagę poświęcono

\footnotetext{
108 Ibidem, k. 11-12.

109 Ibidem, k. 12-13.

110 Prawdopodobnie chodzi o ppłk. Juliana Konara.

111 AIPN, MSW, BU 00231/1, Żołnierze i oficerowie RAF, t. 14, Pismo płk. Józefa Jurkowskiego, szefa WUBP w Gdańsku do Naczelnika Wydz. II Dep. I MBP w Warszawie z 27 VIII
} 
Ludwikowi Pączkowskiemu, byłemu adiutantowi 317 DM. Znalazł się on w kręgu zainteresowania UBP wcześniej, w ramach sprawy o kryptonimie „Port”. Sprawą od lipca 1948 r. zajmował się Departament I Wydziału II MBP i była ona odpryskiem śledztwa prowadzonego przeciwko oskarżonemu o szpiegostwo Władysławowi Śliwińskiemu, byłemu pilotowi Dywizjonu 303. Jednym $z$ aresztowanych był wówczas Marian Cholewka, w przeszłości pilot 317 DM, którego podejrzewano o spotkania z Pączkowskim w Gdańsku. Miał uzyskać wtedy informacje dotyczące handlu zagranicznego, które następnie przekazał do Anglii. Śledztwo nie potwierdziło tych podejrzeń, nie stwierdzono też, by Pączkowski zajmował się działalnością wywiadowczą. Dodatkowo „Pączkowski Ludwik został zwerbowany przez Sekcję VI Wydz. I na uczuciach patriotycznych i figuruje pod ps. «S.18»". Dlatego włączono go do operacji "Mewa”"112.

5 sierpnia 1949 r. lotnikami PSP zainteresowano się w olsztyńskim WUBP. Tutaj nie „dorabiano ideologii” do rozpoczęcia pracy, uzasadniono ją krótko: „Melduję, że dnia 5 VIII 1949 r. przystąpiono do rozpracowania obiektowego b. żołnierzy rdzennie brytyjskich sił zbrojnych w Anglii jako element podatny do współpracy z wywiadem angielskim" ${ }^{113}$. Według rozeznania funkcjonariuszy WUBP na terenie woj. olsztyńskiego znajdowało się ośmiu żołnierzy służących w czasie wojny na terenie Wielkiej Brytanii. Dwóch z nich nie było jednak lotnikami. Z pozostałych sześciu aż czterech wydało się podejrzanych z racji wykonywanego zawodu - jeden był kierownikiem Oddziału Lotnictwa Cywilnego (jedynej placówki związanej z lotnictwem na terenie woj. olsztyńskiego), trzech innych zatrudnionych było w Urzędzie Wojewódzkim, a więc mogli prowadzić wrogą ustrojowi działalność w administracji publicznej. W dokumencie stwierdzono: „Ogólnie rzecz biorąc, należy stwierdzić, że członkowie tego obiektu mają możność do prowadzenia wywiadow-

1949 r. (L.dz. AB-4200/49), k. 18; Pismo płk. Stefana Antosiewicza, Dyrektora Departamentu I MBP do gen. bryg. Wacława Komara, Dyrektora Departamentu VII MBP z 19 IX 1949 r. (L.dz. BA-463/49), k. 18; Pismo gen. bryg. Wacława Komara, Dyrektora VII Departamentu MBP do płk. Stefana Antosiewicza, Dyrektora I Departamentu MBP z 3 XI 1949 r. (L.dz. 194/49) wraz z notatką informacyjną o por. Semmerlingu, k. 22-23; Pismo płk. Józefa Jurkowskiego, Szefa Woj. Urzędu Bezp. Publ. w Gdańsku do Naczelnika Wydziału II Dep. I Ministerstwa Bezpieczeństwa Publicznego w Warszawie z 12 XI 1949 r. (L.dz. AB-5032/49), k. 24.

112 AIPN, MSW, BU 00231/1, Postanowienie o zaniechaniu sprawy pod kryptonimem „Port” i przekazaniu materiałów do WUBP - Gdańsk celem włączenia do rozpracowania obiekt. „Mewa”, pismo Jerzego Omyckiego, mł. ref. Sek. III Wydz. II Dep. I MBP z 1 X 1949 r. zatwierdzone przez ppłk. Juliana Konara. Naczelnika Wydziału II Dep. I MBP, k. 20-21.

113 AIPN, MSW, BU 00231/1, Żołnierze i oficerowie RAF, t. 15, Meldunek ppłk. Henryka Palki, szefa WUBP w Olsztynie do Naczelnika Wydziału II Departamentu I MBP o wszczęciu rozpracowania obiektowego z 19 VIII 1949 r. (L.dz. DS.-3079/49), k. 10. 
czej działalności na naszym terenie, lecz nasze krótkotrwałe rozpracowanie nie pozwoliło nam dotychczas na prześwietlenie ich właściwej działalności"114. Wynikało to $\mathrm{z}$ niewykorzystania agentury do zebrania informacji, a dane pochodziły głównie z RKU. Dlatego głównym zadaniem, które przed sobą postawili olsztyńscy funkcjonariusze, było stworzenie sieci informatorów obejmującej swoim zasięgiem najbliższe otoczenie osób związanych z „Mewą”.

Meldunek z 26 października 1949 r. ${ }^{115}$ przedstawiał kolejnych żołnierzy służących $\mathrm{w}$ armii brytyjskiej: trzech oficerów, którzy nie byli związani $\mathrm{z}$ lotnictwem oraz dwóch mieszkających w terenie sierżantów służących ponoć w PSP (brak ich nazwisk uniemożliwia potwierdzenie tego faktu ${ }^{116}$ ). Zrezygnowano natomiast ze zdobywania informacji o jednym z lotników pracującym dotychczas w Urzędzie Wojewódzkim, który wyjechał do Białegostoku.

Olsztyńscy funkcjonariusze wciąż nie mieli wystarczających informacji o rozpracowywanych lotnikach: „Otrzymane ostatnio materiały nie ujawniły obecnej wrogiej działalności członków obiektu, ponieważ materiały te uzyskano od informatorów niemających bezpośredniego dotarcia do figurantów i zawierają one informacje ogólne. Uzyskane materiały na ostatnio ustalonych członków obiektu o charakterze informacyjnym odnośnie ich służby $w$ jednostkach angielskich na razie nie pozwalają nam na zorientowanie się, które z tych osób mają uprawiać obecnie wrogą działalność"117. Stało się tak, ponieważ WUBP wciąż nie dysponował agenturą. I właśnie jej stworzenie stało się priorytetem działalności w najbliższym czasie.

W kolejnym raporcie, z 27 grudnia 1949 r. ${ }^{118}$, olsztyńscy funkcjonariusze mogli się już wykazać pewnym sukcesem. Udało im się zwerbować informatora o ps. „Paweł”, który był strażnikiem i pracował razem z jednym z lotników. I na tym kończy się lista efektów dodatnich; w raporcie wciąż dominowało twierdzenie, że wytypowano kandydatów na werbunek.

\footnotetext{
$114 \quad$ Ibidem, k. 13.

115 AIPN, MSW, BU 00231/1, Raport Naczelnika Wydziału I WUBP Olsztyn do Naczelnika Wydz. II Dep. I Ministerstwa Bezpieczeństwa Publicznego w Warszawie o przebiegu rozpracowania obiektowego z 26 X 1949 r. (nr 3071/RO-II/49), k. 14-16.

116 Na podstawie dalszej treści meldunku można wnioskować, że jednym z nich był rzeczywiście lotnik - Romuald Kosiński z Bartoszyc. Ibidem, k. 16.

117 Ibidem, k. 15.

118 AIPN, MSW, BU 00231/1, Raport Naczelnika Wydziału I WUBP Olsztyn o przebiegu rozpracowania obiektowego z 27 XII 1949 r. (nr DB 4362/49), k. 17-21.
} 
W Rzeszowie lotnikami zainteresowano się 8 sierpnia ${ }^{119}$. Początkowo ustalono pięciu lotników - trzech w Rzeszowie oraz po jednym w Sanoku i Lubaczowie. Poza tym powiatowy UBP w Mielcu meldował o siedmiu osobach zatrudnionych w tamtejszej Wytwórni Sprzętu Komunikacyjnego (WSK), ale dane te nie zostały potwierdzone. Ponieważ lotnicy zamieszkali w Rzeszowie także byli zatrudnieni w tamtejszej WSK, funkcjonariusze UBP widzieli w figurantach zagrożenie dla rodzimego przemysłu lotniczego. Spośród wspomnianych pięciu lotników czterech było członkami PZPR, co zostało skwitowane: „Po przyjeździe do kraju wstąpili do partii i w obecnej chwili są członkami PZPR i starają się o zaufanie u władz partyjnych, pomimo że w przeszłości byli oni zwolennikami sanacji lub endecji” ${ }^{120}$.

WUBP w Rzeszowie nie dysponował agenturą użyteczną w sprawie „Mewy”, bo - jak się tłumaczyli funkcjonariusze - obiekt jest dopiero założony. Aby to zmienić, zamierzano m.in. znaleźć kandydatów na werbunek oraz zbudować sieć agencyjno-informacyjną, której celem miało być dotarcie do figurantów w miejscu pracy i zamieszkania. Dodatkowo planowano skupić się na znalezieniu kolejnych lotników, przeprowadzić wśród nich selekcję, a następnie wytypować tych, którzy warci byli głębszego rozpracowania.

Do końca 1949 r. WUBP w Rzeszowie nie podjął żadnych działań wywiadowczych związanych z „Mewą”. Jedyna sprawa, która związana była z lotnictwem, dotyczyła Tadeusza Rogolińskiego, technika lotniczego, który został aresztowany w związku z pożarem, do którego doszło w kwietniu 1949 r. w rzeszowskiej WSK. Spłonęły wtedy dwa cenne silniki będące wzorcowymi do planowanej produkcji. Jako że Rogoliński był w czasie wojny oficerem PSP i zeznał, że tuż przed opuszczeniem Wielkiej Brytanii spotkał się z przedstawicielami tamtejszego wywiadu, znalazł się w kręgu zainteresowań „Mewy”. Tyle tylko, że zainteresowanie to ograniczyło się jedynie do zapoznania z treścią zeznań lotnika.

15 września 1949 r. „Mewę” rozpoczęto w Lublinie ${ }^{121}$. Lublińscy funkcjonariusze ustalili 24 osoby, które w czasie wojny mogły być związane z lotnictwem. Do ich rozpracowania dysponowano jedynie informatorem „Marchewką", który na dodatek miał kontakt tylko z jednym figurantem. Cele, które sobie wyznaczono, nie odbiegały zasadniczo od początkowych działań podjętych w innych województwach: zbieranie informacji o lotnikach,

\footnotetext{
119 Ibidem, k. 17.

120 Ibidem, k. 17.

121 AIPN, MSW, BU 00231/1, Żołnierze i oficerowie RAF, t. 20, Meldunek ppłk. Artura Jastrzębskiego, szefa WUBP w Lublinie do MBP (Dep. I Wydz. II) o wszczęciu rozpracowania obiektowego kr. „Mewa” z 29 IX 1949 r., k. 14.
} 
poszukiwanie nowych figurantów i tworzenie sieci informacyjnej oraz agenturalnej ${ }^{122}$.

Meldunek o wszczęciu „Mewy” w Lublinie spotkał się z odzewem ppłk. Konara - niecały miesiąc później, 27 października, zlecił on bowiem dokładniejsze rozpoznanie pięciu osób ${ }^{123}$. Ponieważ brak było reakcji ze strony lublińskich funkcjonariuszy, 9 grudnia 1949 r. wysłane zostało pismo ponaglające ${ }^{124}$. Nie przyniosło to jednak efektu aż do połowy stycznia następnego roku.

Najpóźniej, bo 10 października 1949 r., wszczęto „Mewę” w Szczecinie ${ }^{125}$. Szczecińscy funkcjonariusze dotarli do danych 41 lotników oraz 10 osób $\mathrm{z}$ innych formacji walczących w czasie wojny na Zachodzie. Spośród nich do rozpracowania wyznaczono 17 - w tym czterech ze Szczecina, trzech ze Słupska i dwóch ze Stepnicy, pow. Kamień Pomorski ${ }^{126}$. Jednocześnie podkreślano, że „Zebrane jednak wstępne dane o ww. elemencie wskazują nam, że jest to element wrogi i chociażby na zajmowane stanowisko w życiu politycznym i gospodarczym, może stanowić poważną bazę dla obcego wywiadu"127. Brak agentury uniemożliwiał jednak zdobycie niezbędnych informacji mogących rozwinąć sprawę. W związku z tym właśnie rozwój agentury i sieci informatorów stał się najważniejszym problemem, który planowano jak najszybciej rozwiązać. Do końca roku nie wysłano jednak żadnego meldunku informującego o działaniach podjętych w ramach „Mewy”, mimo iż ppłk Konar 28 listopada 1949 r. wysłał dodatkowe instrukcje dotyczące podjęcia kolejnych działań ${ }^{128}$. Ograniczono się do ściągnięcia z Warszawy informacji na temat Stanisława Bochniaka oraz wystąpiono o udostępnienie danych dotyczących nowego figuranta - Edwarda Szymańskiego ze

\footnotetext{
122 Ibidem, k. 17.

123 Stefan Mrugało, Stanisław Laskowski, Antoni Rak, Kazimierz Drejewicz i Czesław Zalewski. AIPN, MSW, BU 00231/1, Pismo płk. Juliana Konara do Naczelnika Wydziału I Wojewódzkiego Urzędu Bezpieczeństwa Publicznego w Lublinie z 27 X 1949 r. (BA-512/49), k. 19.
}

124 AIPN, MSW, BU 00231/1, Pismo płk. Juliana Konara do Naczelnika Wydziału I Wojewódzkiego Urzędu Bezpieczeństwa Publicznego w Lublinie z 9 XII 1949 r., k. 19.

125 AIPN, MSW, BU 00231/1, Żołnierze i oficerowie RAF, t. 18, Meldunek szefa WUBP w Szczecinie do Naczelnika Wydziału II Departamentu I MBP o wszczęciu rozpracowania obiektowego z 19 X 1949 r. (L.dz. R.O.-6/49), k. 14.

126 Stanisław Bochniak, Czesław Śnieć, Janusz Kozubowski, Marian Adamaszek, Antoni Toczek, Stanisław Sokół, Stanisław Szczytowski, Zdzisław Karpiński, Jerzy Zieliński, Władysław Łukowski, Aleksander Pogorzelski, Jan Chromcewicz, Alfred Bomba, Marian Brusanowski, Kazimierz Kujawa, Antoni Nadrejkowski oraz Leon Glassner. Ibidem, k. 14-21.

127 Ibidem, k. 21.

128 AIPN, MSW, BU 00231/1, Pismo ppłk. Juliana Konara, Naczelnika Wydz. II Dep. I MBP do Nacz. Wydziału I Wojewódzkiego Urzędu Bezp. Publ. w Szczecinie z 28 XI 1949 r. (BA601/49), k. 28. 
Szczecina, który wcześniej miał być pracownikiem urzędu bezpieczeństwa w Krakowie ${ }^{129}$.

Rozpracowanie „Mewa” nabrało tempa na początku 1950 r. W tym czasie do Ministerstwa Bezpieczeństwa Publicznego skierowany został, zatrudniony do tej pory w WUBP w Szczecinie, ppor. Zbigniew Piotr Sokół. Ten pochodzący $\mathrm{z}$ Lublina 23-letni ${ }^{130}$ funkcjonariusz pracę $\mathrm{w}$ strukturach podległych MBP rozpoczął w kołobrzeskim PUBP 20 października 1945 r. Jego umiejętności szybko zostały dostrzeżone i po przejściu ścieżki od młodszego referenta, poprzez sekretarza i referenta ewidencji operacyjnej, po oficera śledczego 23 lutego 1948 r. został przeniesiony do Szczecina. Był tam początkowo referentem, a od 1 sierpnia 1949 r. starszym referentem Wydziału ds. Funkcjonariuszy. 7 grudnia 1949 r. trafił do Warszawy, do Wydziału II Departamentu I, pod komendę ppłk. Konara, który zlecił młodemu funkcjonariuszowi kontrolę nad pracą jednostek terenowych zaangażowanych w rozpracowanie „Mewa”.

12 stycznia 1950 r. ppor. Sokół przeprowadził rozmowy telefoniczne z 14 kierownikami Sekcji II w Wydziale II wojewódzkich UBP ${ }^{131}$. Oficer polecił, by w ciągu czterech dni, do 16 stycznia, przesłać na jego ręce wykaz osób związanych w czasie wojny z PSP. Zestawienie zawierać miało informacje, w jakich jednostkach na Zachodzie służyli lotnicy oraz gdzie obecnie pracują. Poza tym kierownicy mieli podać, kto z byłych lotników został zwerbowany. Jak zapisał w notatce służbowej ppor. Sokół: „Kierownicy przyżekli [sic!] do 16 I [19]50 r. nadesłać żądane wykazy”132.

4 lutego 1950 r. ppłk Konar rozesłał pismo ponaglające do wojewódzkich urzędów bezpieczeństwa publicznego, które miało usystematyzować sposób zdobywania informacji. W instrukcji tej czytamy m.in. „Dotychczas posiadane przez nas dane odnośnie działalności RAF-u, aczkolwiek niekompletne, nasuwają przypuszczenie, że wielu z nich przebywających obecnie w Kraju, uprawia działalność wywiadowczą lub dywersyjną.

Chcąc skuteczniej i aktywniej rozpracować środowisko RAF-u, trzeba zebrać o nim wszelkie bliższe dane dotyczące struktury, zadań stawianych przed poszczególnymi jednostkami, oraz powiązań z Anglikami i dowództwem angielskim.

\footnotetext{
129 AIPN, MSW, BU 00231/1, Pismo Naczelnika Wydziału I Wojewódzkiego Urzędu Bezpieczeństwa Publicznego w Szczecinie do Naczelnika Wydziału II Dep. I Ministerstwa Bezpieczeństwa Publicznego w Warszawie z 19 XI 1949 r. (L.dz. A.5841/49/1039), k. 29.

130 Urodził się 22 VI $1926 \mathrm{r}$.

131 Łódź, Gdańsk, Kielce, Wrocław, Bydgoszcz, Katowice, Poznań, Warszawa, Kraków, Olsztyn, Szczecin, Lublin, Białystok i Rzeszów.

132 AIPN, MSW, BU 01355/1, Krypt. „Mewa”, Notatka służbowa ppor. Zbigniewa Sokoła z 13 I 1950 r., k. 1.
} 
W tym celu należy:

W przypadku aresztowania lub zwerbowania «Rafowca», wyciągnąć od niego maksimum wiadomości o RAF-ie jak:

1. Historia założenia i struktura RAF-u.

2. Skład osobowy głównego sztabu RAF-u, jego siedziba i dowódcy poszczególnych dywizjonów.

3. Jakie zadania miała poszczególna jednostka RAF-u.

4. Jakie kursy - przeszkolenia przechodzili członkowie RAF-u (dokładne dane o tych kursach).

5. Kto obsługiwał daną jednostkę RAF-u z ramienia angielskich władz wojskowych.

6. Co wiadomo im jest o oficerach informacyjnych w jednostkach RAF-u, oraz oficerach II Oddziału, działających na terenie RAF-u (dokładne charakterystyki tych ludzi i ich działalność).

7. Co wie o oficerach angielskiego wywiadu i kontrwywiadu, działających na terenie RAF-u oraz osobach - Polakach, współpracujących z nimi. (Szczegółowe charakterystyki tych Polaków i ich działalności z uwzględnieniem obecnego miejsca zamieszkania - pracy).

8. Dokładne dane o RAF-owcach, przebywających w Polsce, znanych mu $\mathrm{z}$ terenu Anglii.

Dane te po skompletowaniu stanowić będą poważny wkład w ogólną ocenę RAF-u oraz pozwolą na zastosowanie odpowiednich metod w celu rozszyfrowania obecnej działalności RAF-owców"133. Instrukcja ta spowodowała, że „Mewa” wkroczyła w nowy etap.

Inwigilacja przybyłych z Zachodu żołnierzy przez UBP nie musiała wiązać się z centralnie zorganizowaną akcją typu „Mewa”, „Tobruk”"134, „Centro-Zachód”135 czy też „Targowica"136. Brano pod lupę i sprawdzano osoby z różnych powodów. Nim doszło do rozpoznania funkcjonowania w Polsce „byłych RAF-owców”, pojawiały się sprawy i rozpracowania, które powodowane były innymi czynnikami niż przynależność np. do Polskich Sił Powietrznych. Takim przykładem jest rozpracowanie operacyjne „Londyn II”, którego głównym figurantem był kpt. pil. Edward Jaworski.

133 AIPN, MSW, BU 01355/1, Krypt. „Mewa”, Pismo Naczelnika Wydziału II Departamentu I, ppłk. Juliana Konara z 4 II 1950 r., k. 2-3.

134 Sprawa obiektowa o kryptonimie „Tobruk” dotyczyła byłych żołnierzy Polskich Sił Zbrojnych na Zachodzie oraz ich rodzin, powracających po II wojnie światowej do Polski, założona i prowadzona przez PUBP w Kaliszu.

135 Sprawa obiektowa „Centro-Zachód” dotyczyła byłych żołnierzy Polskich Sił Zbrojnych na Zachodzie oraz reemigrantów, prowadzona przez PUBP w Bydgoszczy.

136 Sprawa obiektowa nosząca kryptonim „Targowica” dotycząca żołnierzy armii gen. Władysława Andersa oraz Oddziału VI Sztabu Naczelnego Wodza. 
Edward Jaworski ${ }^{137}$ powrócił do kraju 22 lipca 1947 r. na pokładzie brytyjskiego statku „Eastern Prince”"138. Został skierowany do obozu repatriacyjnego w Gdańsku, gdzie w ciągu trzech dni załatwił formalności rejestracyjne. 26 lipca dotarł pociągiem do Trzebini, do rodzinnego domu ${ }^{139}$. Po rejestracji w RKU w Wadowicach rozpoczął poszukiwanie pracy, bowiem zdemobilizowano go. W związku z trudnościami z jej znalezieniem rozpoczął kurs księgowości, jednocześnie starał się nie tracić kontaktu z kolegami z czasów służby w wojsku. Podyktowane to było nie tylko większą szansą na znalezienie pracy, ale także ewentualnymi możliwościami służby w powietrzu. Niezwykle cenne były spotkania $\mathrm{z}$ tymi, którzy wrócili wcześniej do Polski i już pracowali, tak jak z Jerzym Szymankiewiczem ${ }^{140}$, który - będąc

137 Edward Jaworski (ur. 16 V 1920 w Trzebinie - zm. 26 IX 2012), syn Franciszka i Wiktorii z domu Głowackiej. Po ukończeniu 7-klasowej szkoły powszechnej w Trzebini kontynuował naukę w gimnazjum im. Stanisława Staszica w Chrzanowie, w którym zdał maturę w maju 1938 r. 3 I 1939 r. rozpoczął naukę w Szkole Podchorążych Lotnictwa w Dęblinie, którą zakończył w sierpniu 1939 r. kursem specjalizacji myśliwskiej. W kampanii polskiej 1939 r. udziału nie brał. Ewakuowany z całym rocznikiem z Dęblina, 18 września przekroczył granicę rumuńską. Internowany, uciekł z obozu i 29 października dotarł do Francji. Od 16 grudnia w Centrum Wyszkolenia Lotnictwa w Lyon-Bron. W kampanii francuskiej nie brał udziału. Ewakuowany 20 czerwca do Wielkiej Brytanii, gdzie 6 XI 1940 r. rozpoczął szkolenie. 15 VI 1941 r. otrzymał przydział do 315 DM. 1 III 1944 r. skierowany do 317 DM, z którym uczestniczył w inwazji w Normandii. Od 30 sierpnia w 302 DM jako dowódca eskadry. 1 II 1945 r. przeniesiony do sztabu 131 Skrzydła Myśliwskiego, gdzie pełnił funkcję oficera taktycznego. 1 września dostał przydział do 308 DM, w którym służył do jego rozformowania na początku 1947 r. Wojnę zakończył w stopniu polskiego kapitana. Został odznaczony Krzyżem Srebrnym VM, trzykrotnie KW, brytyjskim Distinguished Flying Cross. Zob. Archiwum Instytutu Pamięci Narodowej w Krakowie (dalej AIPN Kr), Wojewódzki Urząd Spraw Wewnętrznych w Krakowie (dalej WUSW w Krakowie), 009/4302, t.1, Teczka personalna informatora ps. „Olek” dot. Edward Jaworski, imię ojca: Franciszek, ur. 18-05-1920 r., Moja działalność, b.d., k. 12-199; IPiMS, Akta Polskich Sił Powietrznych na zachodzie 1935-1947, LOT.A.V.1/4/XXIV, Ewidencja bojowa pilotów, k. 179; CAW-WBH, II.56.6255, Rejestracyjny spis żołnierzy powracających do Polski na stałe miejsce zamieszkania z jednostek wojskowych za granicą, k. 89; E. Jaworski, Zranione skrzydło. Wspomnienia zielonogórzanina pilota polskich dywizjonów myśliwskich RAF odznaczonego Orderem Virtuti Militari, Zielona Góra 1995.

138 CAW-WBH, Kolekcja akt żołnierzy polskich powracających z Polskich Sił Zbrojnych na Zachodzie 1945-1948, sygn. II.56.6255, Rejestracyjny spis żołnierzy powracających do Polski na stałe miejsce zamieszkania z jednostek wojskowych za granicą, k. 9; E. Jaworski, Zranione skrzydło..., s. 176-178; AIPN Kr, WUSW w Krakowie, 009/4302, t.1, Teczka personalna informatora ps. „Olek” dot. Edward Jaworski, imię ojca: Franciszek, ur. 18-05-1920 r., k. 16.

139 AIPN Kr, WUSW w Krakowie, 009/4302, t.1, Teczka personalna informatora ps. „Olek” dot. Edward Jaworski, imię ojca: Franciszek, ur. 18-05-1920 r., Moja działalność, b.d., k. 16.

140 Jerzy Szymankiewicz (ur. 1 II 1918 w Warszawie), kpt. pil. syn Mieczysława i Władysławy z domu Patkiewicz. Maturę w zdał czerwcu 1938 r. w Gimnazjum Państwowym im. Władysława IV w Warszawie. Absolwent XIV Szkoły Podchorążych Lotnictwa w Dęblinie. W PSP służył w 316 DM, 302 DM (dowódca jednostki od 18 XII 1945 r. do 15 IX 1946 r.), Wojnę zakończył w stopniu kapitana. Za służbę w PSP został uhonorowany Srebrnym 
pilotem w PLL „LOT” - po wylądowaniu w Gliwicach po jednym z lotów odwiedził przyjaciela w październiku $1947 \mathrm{r}^{141}$

Brak pracy i niespodziewane kłopoty ze spłatą pożyczki zaciągniętej przez ojca w Komunalnej Kasie Oszczędnościowej zmusiły Jaworskiego do zwrócenia się o pomoc do kolegi z lotnictwa, Antoniego Węgrzyna ${ }^{142}$. Jeszcze przed wyjazdem do Polski Węgrzyn zaproponował Jaworskiemu taką formę dostarczenia pieniędzy z odprawy demobilizacyjnej, by nie tracić na transferze pieniądza poprzez banki. Antoni Węgrzyn wysyłał swojemu ojcu towary, które były w Polsce nieosiągalne. Ten sprzedawał je, a zarobione $\mathrm{w}$ ten sposób złotówki przesyłał osobom, które powierzyły jego synowi w Wielkiej Brytanii funty ${ }^{143}$.

Jaworski wzbudził zainteresowanie UB, gdy dotarł do niego przekaz pocztowy na kwotę 20 tys. $z^{144} .22$ października 1947 r. naczelnik Wydziału I WUBP w Krakowie kpt. Józef Grotte ${ }^{145}$ przesłał do podległego mu urzędu w Chrzanowie zlecenie wszechstronnego wywiadu na temat lotnika. PUB w Chrzanowie miał problemy z wykonaniem zadania, bowiem na początku stycznia $1948 \mathrm{r}$. figurant wyjechał do Krakowa ${ }^{146}$. Nieobecność Jaworskiego związana była nie tylko $\mathrm{z}$ poszukiwaniem pracy, ale także ze spotkaniami z dawnymi towarzyszami broni. W listopadzie 1947 r. odwiedzili Edwarda w Chrzanowie dwaj

Krzyżem VM, czterokrotnie KW, a także brytyjskim Distinguished Flying Cross. Do Polski powrócił 21 XI 1946 r. Zob. IPiMS, Akta Polskich Sił Powietrznych na zachodzie 1935-1947, LOT.A.V.1/4/XXIV, Ewidencja bojowa pilotów, k. 131; AIPN, Stołeczny Urząd Spraw Wewnętrznych w Warszawie, BU 0423/3463, Sprawa operacyjna dot. Jerzy Szymankiewicz, imię ojca: Mieczysław, ur. 01-02-1918 r., k. 34.

${ }^{141}$ AIPN Kr, WUSW w Krakowie, 009/4302, t.1, Teczka personalna informatora ps. „Olek” dot. Edward Jaworski, imię ojca: Franciszek, ur. 18-05-1920 r., Moja działalność, b.d., k. 16.

142 Antoni Węgrzyn (ur. 18 V 1916 w Krakowie - zm. 1972), syn Karola, por. pil. Maturę zdał w gimnazjum w Krakowie w 1936 r. Absolwent XIII promocji Szkoły Podchorążych Lotnictwa w Dęblinie. Podczas wojny służył w dywizjonach PSP: 306 DM, 317 DM, 302 DM. 10 II 1945 r. zestrzelony podczas lotu bojowego, lądował przymusowo 10 mil na zachód od Münchengladbach. Trafił do niemieckiej niewoli, z której powrócił 12 V 1945 r. Wojnę zakończył w stopniu porucznika. Za udział w lotach bojowych w czasie wojny odznaczony trzykrotnie KW. Do kraju nie powrócił. Zob. IPiMS, Akta Polskich Sił Powietrznych na zachodzie 1935-1947, LOT.A.V.1/4/XXIV, Ewidencja bojowa pilotów, k. 165; CAW-WBH, Centrum Wyszkolenia Lotnictwa nr 1, sygn. I.340.49.14 i I.340.49.15.

143 AIPN Kr, WUSW w Krakowie, 009/4302, t. 1, Teczka personalna informatora ps. „Olek” dot. Edward Jaworski, imię ojca: Franciszek, ur. 18-05-1920 r., Moja działalność, b.d., k. 16.

144 W 1949 r. w Polsce przeciętna płaca wynosiła 11000 zł.

145 AIPN Kr, WUSW w Krakowie, 009/4302, t. 2, Akta rozpracowania agenturalnego kryptonim „Londyn II” dot. Edward Jaworski, imię ojca: Franciszek, ur. 18-05-1920 r. Kontrola operacyjna b. pilota RAF i repatrianta z Anglii w związku z podejrzeniem o działalność o charakterze wywiadowczym, Dot.: Jaworskiego Edwarda, 24 X 1947 r., k. 6.

146 AIPN Kr, WUSW w Krakowie, 009/4302, Do Wojew. Urzędu Bezp. Publ. w odpowiedzi na pismo z 10.12.47 r. Nr. 253-2422/CB-C/47 dotyczy: Edward Jaworski, Kraków 22 I 1948 r., k. 7. 
koledzy z lotnictwa: Bolesław Jedliczko i Marian Cholewka ${ }^{147} .8$ grudnia Jaworski otrzymał telegram, by przyjechał do Kutna do Czesława Śniecia ${ }^{148}$, który wrócił do kraju z rodziną. W drodze powrotnej, korzystając z okazji, zatrzymał się w Sosnowcu, by dowiedzieć się, czy jest szansa na otrzymanie etatu w Zjednoczeniu Węglowym. W styczniu 1948 r., wciąż poszukując pracy, pojechał do Katowic, by starać się o przyjęcie do Centrali Handlu Skórzanego ${ }^{149}$. W tym czasie Wydział I WUBP w Krakowie wysyłał pismo za pismem, by poddać szczegółowej inwigilacji figuranta i zwerbować agenturę, która ułatwiłaby to zadanie ${ }^{150}$. Pierwszy meldunek dotyczący Edwarda Jaworskiego z chrzanowskiej

147 Marian Cholewka (ur. 30 III 1915 w Blanowicach - zm. 27 XI 1964), syn Antoniego i Michaliny z domu Gębka, kpt. pil. Absolwent Szkoły Podchorążych Rezerwy Lotnictwa w Dęblinie. W PSP służył w 317 DM, 316 DM. Podczas operacji „Jubilee”, w locie bojowym 19 VIII 1942 r., został ciężko ranny w ramię, które później amputowano. Wojnę zakończył w stopniu kapitana. Za służbę podczas wojny uhonorowano go Krzyżem Srebrnym VM, KW, Odznaką Honorową za Rany i Kontuzje. Do kraju powrócił 22 VII 1947 r. CAW-WBH, Kolekcja akt żołnierzy polskich powracających z Polskich Sił Zbrojnych na Zachodzie 19451948, sygn. II.56.6255, Rejestracyjny spis żołnierzy powracających do Polski na stałe do miejsce zamieszkania z jednostek wojskowych za granicą, k. 88; IPiMS, Akta Polskich Sił Powietrznych na zachodzie 1935-1947, LOT.A.V.1/4/XXIV, Ewidencja bojowa pilotów, k. 22; Archiwum Instytutu Pamięci Narodowej w Katowicach (dalej AIPN Ka), Wojewódzki Urząd Spraw Wewnętrznych w Katowicach (WUSW w Katowicach), 230/2087, Sprawa operacyjna dot. Cholewka Marian, imię ojca: Antoni, ur. 30-03-1915 r. Kontrola operacyjna byłego oficera PSZ na Zachodzie, pilota RAF, Życiorys, b.d., k. 12.

148 Czesław Śnieć (ur. 30 I 1919 w Kutnie - zm. 13 IV 1972), syn Stanisława i Czesławy, kpt. pil. W 1929 r. ukończył szkołę powszechną. Naukę kontynuował w gimnazjum im. H. Dąbrowskiego w Kutnie, w którym zdał maturę w czerwcu 1938 r. Absolwent XIV promocji Szkoły Podchorążych w Dęblinie. W PSP służył w: 317 DM, 302 DM. 8 IX 1943 r. nie powrócił z lotu bojowego nad Lille we Francji. Ukrywał się we Francji, gdzie 23 listopada przekroczył granicę francusko-hiszpańską. W Hiszpanii uwięziony w obozie Miranda de Ebro, został uwolniony 6 I 1944 r. Wojnę zakończył w stopniu kapitana. Odznaczony został Krzyżem Srebrnym VM, trzykrotnie KW, Złotym Krzyżem Zasługi z Mieczami, a także brytyjskim Distinguished Flying Cross. 16 XI 1946 r. złożył podanie o zwolnienie z wojska, które otrzymał 26 IV 1947 r. Wyjechał do Belgii do rodziny żony. Do Polski wrócił 1 XII 1947 r. Zob. IPiMS, Akta Polskich Sił Powietrznych na zachodzie 1935-1947, LOT.A.V.1/4/XXIV, Ewidencja bojowa pilotów, k. 131; AIPN Ka, WUSW w Katowicach, 0/4/3468, Materiały dot. Śnieć Czesław, imię ojca: Stanisław, ur. 30-01-1919 r., byłego oficera PSZ na Zachodzie, b.d., k.10.

149 AIPN Kr, WUSW w Krakowie, 009/4302, t. 1, Teczka personalna informatora ps. „Olek” dot. Edward Jaworski, imię ojca: Franciszek, ur. 18-05-1920 r., Moja działalność, b.d., k. 163.

150 AIPN Kr, WUSW w Krakowie, 009/4302, t.2, Akta rozpracowania agenturalnego kryptonim „Londyn II” dot. Edward Jaworski, imię ojca: Franciszek, ur. 18-05-1920 r. Kontrola operacyjna b. pilota RAF i repatrianta z Anglii w związku z podejrzeniem o działalność o charakterze wywiadowczym, Moja działalność, b.d., k. 10; t. 3, Akta rozpracowania agenturalnego kryptonim „Londyn II” dot. Edward Jaworski, imię ojca: Franciszek, ur. 18-051920 r. Kontrola operacyjna b. pilota RAF i repatrianta z Anglii w związku z podejrzeniem o działalność o charakterze wywiadowczym, Wstępny plan agenturalnego rozpr. „Londyn II”, k. 37. Rozpracowanie operacyjne o nazwie „Londyn” zostało założone 22 X 1945 r. po odkryciu, że duża liczba przesyłek z zagranicy z towarami trudno dostępnymi na polskim 
bezpieki dotarł do WUB w Krakowie dopiero 8 czerwca 1948 r. Meldowano w nim o wizytach figuranta w klasztorze salwatorian, a także unikaniu przez niego kontaktu z miejscową ludnością. Do inwigilacji lotnika udało się zwerbować dwóch agentów o pseudonimach „Marynarz” i „Bzura”, którzy próbowali rozpracować kontakty inwigilowanego już w lutym 1948 r. Jednak ich pomoc była niewystarczająca ${ }^{151}$.

W połowie stycznia do Trzebini przyjechał Bolesław Jedliczko, który zaproponował Jaworskiemu pracę $\mathrm{w}$ sieci wywiadowczej, za którą byłby wynagradzany pensją w wysokości $20000 \mathrm{z}^{152}$. Ten ostatni nie odmówil, ale poprosił o czas do namysłu i obiecał, że w ciągu trzech tygodni da odpowiedź. Pod koniec lutego Jaworski pojechał do Warszawy, by w Instytucie Badań Lekarskich przejść badania umożliwiające mu latanie w Aeroklubie Krakowskim. Spotkał się w tym czasie z Jedliczką oraz Cholewką ${ }^{153}$ i wspólnie odwiedzili Władysława Śliwińskiego w jego mieszkaniu przy ul. Filtrowej ${ }^{154}$. W związku z tym, że Jaworski nie odpowiedział listownie na propozycję Jedliczki, tematu tego $\mathrm{w}$ czasie pobytu $\mathrm{w}$ Warszawie nie poruszano. Z końcem lutego do Krakowa przyjechał Czesław Śnieć, z którym Jaworski spotkał się w mieszkaniu Zygmunta Wodeckiego ${ }^{155}$. W trakcie tej wizyty Jaworski odbył

rynku regularnie docierała do Karola Węgrzyna. UB podejrzewał, że przesyłane towary, a następnie ich spieniężanie i rozsyłanie po kraju gotówki związane jest z finansowaniem sieci wywiadowczych lub obserwacyjnych obcych wywiadów. Rozpracowanie ukierunkowane było na prowadzeniu inwigilacji osób, do których dostarczano przekazy lub gotówkę.

151 AIPN Kr, WUSW w Krakowie, 009/4302, t. 1, Teczka personalna informatora ps. „Olek” dot. Edward Jaworski, imię ojca: Franciszek, ur. 18-05-1920 r., Wstępny plan agenturalnych przedsięwzięć rozpracowania „Londyn II”, Warszawa 20 I 1950 r., k. 101.

152 AIPN Kr, WUSW w Krakowie, 009/4302, Moja działalność, Warszawa, b.d., k. 17; t. 3, k. 14, Wyciąg z protokołu przesłuchania podejrzanego Jedliczko Bolesława ps. „Zawadzki” z 6 VI 1948 r., Warszawa, k. 59-60; Wstępny plan agenturalnych przedsięwzięć rozpracowania „Londyn II”, Warszawa 15 I 1949 r., k. 44.

153 AIPN, MSW, BU 942/2814, Akta Mariana Cholewki w sprawie odszkodowania za bezzasadne aresztowanie, Do Obywatela Prokuratora Generalnego Polskiej Rzeczypospolitej Ludowej w Warszawie, 17 XI 1956 r., k. 3. Marian Cholewka został aresztowany 13 VI 1948 r. pod zarzutem szpiegostwa. Łączono jego osobę z Bolesławem Jedliczko i jego pracą w sieci wywiadowczej. 154 AIPN Kr, WUSW w Krakowie, 009/4302, t. 1, Teczka personalna informatora ps. „Olek” dot. Edward Jaworski, imię ojca: Franciszek, ur. 18-05-1920 r., Moja działalność, Warszawa, b.d., k. 16.

155 Wodecki Zygmunt (ur. 17 II 1909 r. w Skawinie - zm. 24 II 1986), syn Zygmunta i Janiny z domu Jaskulska, kpt. W 1929 r. ukończył gimnazjum im. Adama Mickiewicza w Krakowie. W tym samym roku rozpoczął studia na Wydziale Lekarskim Uniwersytetu Jagiellońskiego, uzyskując absolutorium w grudniu 1934 r. W 1935 r. został powołany do szkoły Podchorążych Rezerwy Sanitarnej w Warszawie na sześciomiesięczny kurs, a później na kolejny w Centrum Wyszkolenia Oficerów Lotnictwa w Dęblinie. Od 1 IX 1936 r. do 1 XI 1937 pracował jako instruktor wychowania fizycznego w Young Men's Christian Association (YMCA) w Łodzi, by w listopadzie 1937 r., po powrocie do Krakowa, zdać końcowe egzaminy medyczne. Od 1 II 1939 r. pełnił obowiązki kierownika działu Wojska Polskiego w Polskiej 
rozmowę ze Śnieciem i opowiedział mu zarówno o propozycji Jedliczki, jak i o swojej odmowie ${ }^{156}$.

8 czerwca 1948 r. do WUBP w Krakowie dotarł telefonogram od dyrektora Departamentu I MBP, płk. Artura Jastrzębskiego, który zawierał rozkaz natychmiastowego aresztowania Edwarda Jaworskiego jako członka siatki wywiadowczej stworzonej przez Władysława Śliwińskiego ${ }^{157}$. Nazwisko figuranta padło po raz pierwszy podczas przesłuchania Śliwińskiego $4 \mathrm{czerwca}^{158}$, a potem także 6 czerwca w trakcie indagacji Bolesława Jedliczki ${ }^{159}$. W Krakowie rozkazu jednak nie wykonano. Na telefonogramie widnieje ręczny dopisek „telef. odwołano". Kolejne pismo dotyczące sprawy Jaworskiego adresowane do kpt. Grotte z WUBP w Krakowie dotarło od naczelnika Wydziału II Departamentu I, Juliana Konara, który prosił o informowanie ministerstwa o postępach w rozpracowaniu operacji „Londyn” 160 . W związku z tym, że sprawą Jaworskiego interesowała się także Warszawa, 31 lipca 1948 r., WUBP w Krakowie przesłał do zatwierdzenia plan agenturalnego rozpracowania o kryptonimie „Londyn II”. Miało ono zbadać, czy wobec faktu wykrycia sieci informacyjnej prowadzonej przez Władysława Śliwińskiego nie natrafiono na kolejną, prowadzoną także

YMCA w Krakowie. Zmobilizowany 30 VIII 1939 r. do 2 Pułku Lotniczego, przeszedł z nim szlak bojowy jako lekarz. 20 września przekroczył granicę rumuńską, 13 października odpłynął do Marsylii. Po przybyciu do Francji skierowany został do obozu w Istres, a potem do Lyon-Bron, gdzie służył jako lekarz w Centralnej Izbie Chorych. W lutym 1940 r. dostał przydział do Dywizjonu 1/145, z którym przeszedł szlak bojowy. Po ogłoszeniu kapitulacji Francji dotarł do portu w La Rochelle, z którego odpłynął do Wielkiej Brytanii. 20 VIII 1940 r. otrzymał przydział do 303 DM. W maju 1943 r. odbył czterotygodniowy kurs wychowania fizycznego, po ukończeniu którego odesłano go do Blackpool. Po sześciu miesiącach skierowano go do 317 DM. 1 VII 1945 r. został naczelnym lekarzem 131 Skrzydła Myśliwskiego. Wojnę zakończył w stopniu kapitana. Został odznaczony Krzyżem Walecznych. Do Polski powrócił w październiku 1947 r. Zob. AIPN Ka, Wojewódzki Urząd Spraw Wewnętrznych w Bielsku Białej (dalej WUSW w Bielsku Białej), 0025/199, Teczka personalna informatora ps. „W” dot. Wodecki Zygmunt, imię ojca: Zygmunt, ur. 17-02-1909 r., Protokół przesłuchania podejrzanego Zygmunta Wodeckiego z 11 XI 1952 r., Kraków, k. 113-116.

156 AIPN Kr, WUSW w Krakowie, 009/4302, t. 1, Teczka personalna informatora ps. „Olek” dot. Edward Jaworski, imię ojca: Franciszek, ur. 18-05-1920 r., Moja działalność, Warszawa, b.d., k. 19.

157 AIPN Kr, WUSW w Krakowie, 009/4302, t. 3, Akta rozpracowania agenturalnego kryptonim „Londyn II” dot. Edward Jaworski, imię ojca: Franciszek, ur. 18-05-1920 r. Kontrola operacyjna b. pilota RAF i repatrianta z Anglii w związku z podejrzeniem o działalność o charakterze wywiadowczym, Telefonogram. Do Wojewódzkiego Urzędu Bezp. Publ. w Krakowie, Warszawa 8 VI 1948 r., k. 15.

158 AIPN Kr, WUSW w Krakowie, 009/4302, t. 3, Wyciąg z protokołu przesłuchania podejrzanego Śliwińskiego Władysława z 5 VI 1948 r., [Warszawa], k. 13.

159 AIPN Kr, WUSW w Krakowie, 009/4302, t. 3, Wyciąg z protokołu przesłuchania podejrzanego Jedliczko Bolesława ps. „Zawadzki” z 6 VI 1948 r., [Warszawa], k. 14.

160 AIPN Kr, WUSW w Krakowie, 009/4302, Do Naczelnika Wydz. I WUBP w Krakowie, Kpt. Grotte, b.d., k. 16. 
przez byłych oficerów PSP ${ }^{161}$. 4 sierpnia zlecono stałą obserwację Jaworskiego, której nadano kryptonim „Lotnik”162. Do inwigilacji jednak nie doszło, bowiem pod podanym przez Wydział I Sekcji II adresem w Krakowie Jaworski nie zamieszkiwał. Nakazano PUBP w Chrzanowie ustalenie, czy na terenie miasta zameldowany jest Jaworski. Okazało się, że zamieszanie spowodował fakt, że mieszkający w Chrzanowie lotnik dojeżdżał do Krakowa do pracy w Centrali Handlowej Żelaza i Stali. Taka odpowiedź też dotarła do Krakowa ${ }^{163}$. Po kilku dniach naczelnik Wydziału I WUBP w Krakowie otrzymał informację z Sekcji III Wydziału IV, że Jaworski jednak nie pracuje w Centrali ${ }^{164}$. Dopiero po dwóch tygodniach ostatecznie ustalono, że figurant faktycznie jest tam zatrudniony. 29 października naczelnik Wydziału IV WUBP w Krakowie rozpoczął sprawdzanie otoczenia figuranta, by znaleźć możliwość jego inwigilacji ${ }^{165}$. Ustalono, że Jaworski bardzo rzadko przebywa na terenie aeroklubu w Krakowie, wobec czego polecono, by znaleźć agenturę $\mathrm{w}$ rejonie zamieszkania ${ }^{166}$. Dodatkowo sprawdzano, czy podczas podróży z i do pracy nie kontaktuje się z jakimiś osobami godnymi zainteresowania $\mathrm{UB}^{167}$. Inwigilacja przyniosła efekty i ustalono, że najczęściej przebywał z braćmi Nowakami, Mieczysławem i Tadeuszem, z Trzebini ${ }^{168}$. W związku z tym 20 stycznia 1949 r. zaczęło się sprawdzanie Tadeusza Nowaka, by zorientować się w możliwości jego werbunku' ${ }^{169}$. Wobec nikłych efektów rozpracowania 22 stycznia zlecono kolejną inwigilację „Lotnika”170 28

161 AIPN Kr, WUSW w Krakowie, 009/4302, Plan wstępnego rozpracowania sprawy krypt. „Londyn 2", 31 VII 1948 r., k. 19.

162 AIPN Kr, WUSW w Krakowie, 009/4302, Do Dyrektora Departamentu Śledczego MBP płk. Różańskiego, 11 IV 1949 r., k. 59.

163 AIPN Kr, WUSW w Krakowie, 009/4302, t. 1, Teczka personalna informatora ps. „Olek” dot. Edward Jaworski, imię ojca: Franciszek, ur. 18-05-1920 r., Pismo do WUBP w Krakowie, Wydział I Sekcja II w sprawie przesłania odpisu wywiadu dot. kontaktów zamieszkałych w Warszawie, sprawa Nr. Ag. 235-2422/CB-C/47, kryptonim „Londyn”, 29 IX 1948 r., k. 68.

164 AIPN Kr, WUSW w Krakowie, 009/4302, Do Naczelnika Wydziału I wm. w odpowiedzi na pismo z dnia 11 IX 1948 r. dotyczące ob. Jaworskiego Edwarda, 1 X 1948 r., k. 69.

165 AIPN Kr, WUSW w Krakowie, 009/4302, Prośba o dodatkowe ustalenia do Naczelnika Wydziału IV w związku z pismem z 22.X.48 r. dot. Jaworskiego Edwarda, 29 X 1948 r., k. 74.

166 AIPN Kr, WUSW w Krakowie, 009/4302, Komunikat dla Naczelnika Wydziału I wm. w odpowiedzi na pismo z 19.X.48 r. Nr AG.CB.5/48, 11 XI 1948 r., k. 76.

167 AIPN Kr, WUSW w Krakowie, 009/4302, Raport do Kier. II Sekcji I Wydz. Woj. Urzędu Bezp. Publi. w Krakowie, Chrzanów 11 XI 1948 r., k. 78.

168 AIPN Kr, WUSW w Krakowie, 009/4302, Meldunek do Kier. II Sekcji I Wydz. Woj. Urzędu Bezp. Publi. w Krakowie, Dot: sprawy Ag.-5 krypt. „J”, Chrzanów 15 I 1949 r., k. 97. 169 AIPN Kr, WUSW w Krakowie, 009/4302, Wstępny plan agenturalnych przedsięwzięć rozpracowania „Londyn II”, Kraków 20 I 1949 r., k. 102.

170 AIPN Kr, WUSW w Krakowie, 009/4302, t. 1, Zadanie (na przeprowadzenie obserwacji), Kraków 22 I 1948 r., k. 107. 
lutego w otoczeniu Jaworskiego pojawił się informator o ps. „Wiech”, który był doskonale zorientowany o tym, co i kiedy robi figurant ${ }^{171}$. Mając dzięki „Wiechowi" stały dostęp do informacji o Jaworskim, 24 października 1949 r. w raporcie do Departamentu I Wydziału II MBP o przebiegu agencyjnego rozpracowania sprawy pod kryptonimem „Londyn II” stwierdzono: „nie uzyskaliśmy do chwili obecnej żadnych materiałów, któreby [sic!] wskazywały na wrogą wywiadowczą działalność, co świadczy o tym jego zachowanie wobec agenta, który jest serdecznym jego kolegą z lat dziecinnych"172.

Wobec porażki rozpracowania „Londyn II” między Krakowem a Warszawą rozpoczęły się rozmowy, czy i jak zwerbować Edwarda Jaworskiego ${ }^{173}$. $\mathrm{W}$ tym celu oddelegowano $\mathrm{z}$ Warszawy starszego referenta ppor. Tadeusza Stępnia z Departamentu I Wydziału II Sekcji II, który miał pomóc swoim kolegom z Krakowa podczas werbunku ${ }^{174}$.

16 marca 1949 r., w trakcie powrotu Edwarda Jaworskiego do domu, został on zatrzymany przez pracowników Wydziału I WUBP w Krakowie i doprowadzony do gmachu urzędu ${ }^{175}$. Aresztowania dokonano na tyle dyskretnie, by nikt się zorientował w porwaniu figuranta. Do matki zatrzymanego wysłano telegram, z którego wynikało, że syn wyjechał służbowo, natomiast do pracy wystawiono zaświadczenie lekarskie informujące o chorobie ${ }^{176}$. Przez trzy dni przepytywano Edwarda Jaworskiego na temat jego życiorysu do czasu powrotu do kraju, a także wszystkich zdarzeń, do których doszło po przybyciu do Polski. W trakcie badania stwierdzono, że figurant nie zataił żadnej ze spraw dotyczących przesyłanych pieniędzy, a także próby werbunku przez Bolesława Jedliczkę, napisał także dokładne charakterystyki swoich kolegów przybyłych z Wielkiej Brytanii. 18 marca 1949 r. Edward Jaworski zgodził się na współpra-

171 AIPN Kr, WUSW w Krakowie, 009/4302, Doniesienie ustne, źródło „Wiech”, 28 II 1949 r., k. 123, także raporty z 7 III 1949 r., 14 III 1949 r., 31 III 1949 r., 5 IV 1949 r., 20 IV 1949 r., 27 IV 1949 r., 23 V 1949 r. Nie odnaleziono teczki agenta „Wiech”, ale ustęp z doniesienia może sugerować, że agentem o tym pseudonimie był Tadeusz Nowak: „Co do mojego brata Mieczysława zatrudnionego w Państwowych Zakładach Konfekcyjnych w Bielsku w charakterze inżyniera wyjaśniam, że ww. należy od 1945 r. do PPS, a obecnie PZPR”, ibidem, k. 123.

172 AIPN Kr, WUSW w Krakowie, 009/4302, t. 1, Raport o przebiegu agencyjnego rozpracowania sprawy pod kr. Londyn „II” Ag.5/OB./49, Warszawa 24 X 1949 r., k. 141.

173 AIPN Kr, WUSW w Krakowie, 009/4302, t. 1, Notatka służbowa, b.m. 29 X 1949 r., k. 143.

174 AIPN Kr, WUSW w Krakowie, 009/4302, t. 1, Notatka operacyjna, Kraków 10 I 1950 r., k. 145.

175 AIPN Kr, WUSW w Krakowie, 009/4302, t. 3, Akta rozpracowania agenturalnego kryptonim „Londyn II” dot. Edward Jaworski, imię ojca: Franciszek, ur. 18-05-1920 r. Kontrola operacyjna b. pilota RAF i repatrianta z Anglii w związku z podejrzeniem o działalność o charakterze wywiadowczym, Raport o dokonanym werbunku, Kraków 24 III 1950 r., k. 84. 176 AIPN Kr, WUSW w Krakowie, 009/4302, t. 1, Teczka personalna informatora ps. „Olek” dot. Edward Jaworski, imię ojca: Franciszek, ur. 18-05-1920 r., Raport o dokonanym werbunku, Kraków 22 III 1950 r., k. 8. 
cę z organami bezpieczeństwa publicznego wybierając pseudonim „Olek”177. W zobowiązaniu podpisanym przez Jaworskiego jest akapit: „Zobowiązuję się dobrowolnie i przyrzekam uroczyście, że w współpracy z Organami Bezpieczeństwa będę bronił interesów Polski Ludowej”178.

W podsumowaniu i w deklaracji agenta poinformowano o dobrowolnym podjęciu współpracy, ale wydaje się, że to nie musi być cała prawda. Stępień miał dwa argumenty, którymi mógł szantażować Jaworskiego - brak donosu na Jedliczkę i Śliwińskiego, a za to groziło nawet do 6 lat więzienia, a dodatkowo przewlekła choroba żołądka pilota. Odstawienie leków na kilka dni mogło być dodatkowym źródłem nacisku. Te dwie kwestie ukazują decyzję Edwarda Jaworskiego o współpracy w trochę innym świetle.

$\mathrm{Na}$ marginesie całej sprawy warto dodać, że niespodziewanie zakończyła się współpraca Tadeusza Stępnia z MBP. Z końcem 1950 r. zwolniono go z pracy, po tym jak ujawniono, że zataił fakt służby w „Szarych Szeregach” podczas wojny ${ }^{179}$. Przykład werbunku dokonany w ramach rozpracowania „Londyn II” pokazuje, że po obu stronach barykady mogły pojawić się osoby, które niedawno przelewały krew za tę samą sprawę.

Lotnicy z byłych Polskich Sił Powietrznych znaleźli się w strefie zainteresowania służb bezpieczeństwa publicznego dość szybko. Wpływ na to miała zarówno ich wojenna przeszłość, która wzbudzała podejrzenia o współpracę $\mathrm{z}$ zagranicznym wywiadem, jak również zajmowane $\mathrm{z}$ racji posiadanej wiedzy oraz wykształcenia często ważne i kierownicze stanowiska w istotnych gałęziach polskiej gospodarki. Dotarcie do nich i zdobycie podstawowych danych było jednak początkowo utrudnione ze względu na słabą, dopiero tworzoną siatkę informatorów. Skutkowało to brakiem podstawowej wiedzy o PSP i zaliczaniem do tzw. byłych „Rafowców” osób, które z lotnictwem nie miały nic wspólnego. Sprawiało to, że do 1950 r. potrzebna do rozwoju operacji „Mewa” wiedza była szczątkowa, wyrywkowa i nieusystematyzowana. Trudno też nie odnieść wrażenia, że poświęcano jej więcej czasu w tych wojewódzkich urzędach bezpieczeństwa publicznego, które wyszły z własną inicjatywą rozpracowania lotników byłych PSP. Natomiast tam, gdzie została narzucona przez ppłk. Konara, znajdowała się raczej na bocznym torze zainteresowania funkcjonariuszy i często, mimo ponagleń ze strony centrali, sięgano do niej rzadko lub wcale, zadowalając się wysyłaniem ogólnikowych danych z informacją, że z powodu nawału zadań trudno pchnąć sprawę do przodu. Sytuacja ta trwała do początku 1950 r., kiedy zdenerwowany

177 Ibidem.

178 AIPN Kr, WUSW w Krakowie, 009/4302, t. 1, Zobowiązanie, Kraków 18 III 1950 r., k. 20.

179 Dane osoby z katalogu funkcjonariuszy aparatu bezpieczeństwa, Tadeusz Stępień, https:// www.katalog.bip.ipn.gov.pl/informacje/138370 (dostęp 25 VIII 2019). 
sytuacją ppłk Konar kazał ppor. Sokołowi rozesłać instrukcję porządkującą pracę WUBP w rozpracowaniu operacyjnym „Mewa"180.

\section{Bibliografia}

\section{Źródła}

Archiwum Instytutu Pamięci Narodowej w Warszawie Ministerstwo Spraw Wewnętrznych w Warszawie Stołeczny Urząd Spraw Wewnętrznych w Warszawie Archiwum Instytutu Pamięci Narodowej w Katowicach Wojewódzki Urząd Spraw Wewnętrznych w Bielsku-Białej

Wojewódzki Urząd Spraw Wewnętrznych w Katowicach

Archiwum Instytutu Pamięci Narodowej w Krakowie

Wojewódzki Urząd Spraw Wewnętrznych w Krakowie

Centralne Archiwum Wojskowe Wojskowego Biura Historycznego w Warszawie-Rembertowie

Ministerstwo Obrony Narodowej

Instytut Polski i Muzeum im. gen. Sikorskiego w Londynie

Akta Polskich Sił Powietrznych na zachodzie 1935-1947

\section{Opracowania}

Aparat bezpieczeństwa w Polsce w latach 1954-1956. Taktyka, strategia, metody, wyb. i oprac. G. Majchrzak, A. Paczkowski, Warszawa 2011.

Artymowski S., Od tęsknoty do werbunku. Szkic o przebiegu repatriacji żołnierzy PSZ na Zachodzie do Polski w latach 1945-1948, „Studia Podlaskie” 2010, t. 18.

Bagieński W., Działalność wywiadowcza i kontrwywiadowcza polskich emigrantów w pierwszych latach po II wojnie światowej, „Biuletyn Informacyjny Światowego Związku Żołnierzy Armii Krajowej” 2016, nr 9.

Dubicki T., Suchcitz A., Oficerowie wywiadu WP i PSZ w latach 1939-1945, t. 1, Warszawa 2009.

Kozicki A., Oddział Informacyjny Sztabu II Korpusu w latach 1945-1946: dalsze losy pracowników Oddziału II Sztabu Głównego, „Pamięć i Sprawiedliwość” 2008, nr 2.

Kozicki A., Struktury organizacyjne i formy pracy emigracyjnego wywiadu wojskowego w latach 1945-1955 [w:] W sieci. Powojenne polskie siatki wywiadowcze (AKNIE-DSZ-WiN, PSZ) w latach 1944-1955, red. M. Bechta, Warszawa 2016.

Kubala K., Po prostu miałem szcześsie, „Skrzydlata Polska” 2000, nr 12.

Matusiak W., Powojenne losy elity polskiego lotnictwa, „Biuletyn Instytutu Pamięci Narodowej" 2011, nr 3.

Niwiński P., Wywiad Okręu Wileńskiego AK po lipcu 1944 roku [w:] W sieci. Powojenne polskie siatki wywiadowcze (AK - NIE - DSZ - WiN, PSZ) w latach 19441955, red. M. Bechta, Warszawa 2016.

Politycznie obcy! Żolnierze Wojska Polskiego w zainteresowaniu komunistycznego aparatu represji i propagandy w latach 1944-1956, red. B. Polak, P. Skubisz, Szczecin 2011.

180 AIPN, MSW, BU 00231/1 t. 1, Żołnierze i oficerowie RAF, Projekt instrukcji uzupełniającej do zagadnień rozpr. obiekt. „Mewa”, k. 238-246. 
Polska pod reżimem komunistycznym. Sprawozdanie z sytuacji z kraju (1944-1949), wstęp i oprac. J. Mysiakowska-Muszyńska, W. J. Muszyński, Warszawa 2015.

Sojda G., Porucznika pil. Zdzisława Radomskiego, dzieje niezwykłe..., „Przegląd Historyczno-Wojskowy" 2016, nr 2/3 (256/257).

Sojda G., Za linią wroga, czyli konspiracja porucznika pil. Władysława Śliwińskiego, „Kwarta” 2015, nr 3(16), s. 93-106.

Sojda G., Śliżewski G., Mjr pil. Karol Pniak - pilot akrobacyjny Trójki Bajana, uczestnik Bitwy o Anglię, pilot Polskiego Zespołu Myśliwskiego w Afryce, dowódca 308 Dywizjonu Myśliwskiego Krakowskiego, Warszawa 2015.

Sojda G., Śliżewski G., Hodyra P., Ci cholerni Polacy, Polskie Siły Powietrzne w Bitwie o Anglię, Warszawa 2012.

System represji stalinowskich $w$ Polsce 1944-1956. Represje w marynarce wojennej, red. I. Hałagida, Gdańsk 2003.

Tochman K.A., Gen. Tadeusz Góra - z RAF-u do komunistycznej bezpieki, „Zeszyty Historyczne; Si vis pacem, para bellum: bezpieczeństwo i polityka Polski” 2013, t. 12 .

Tochman K. A., Z ziemi obcej do Polski. Losy żolnierzy Polskich sił Zbrojnych, którzy powrócili do kraju po II wojnie światowej, t. 1, Zwierzyniec - Rzeszów - Londyn 2006.

Tochman K.A., Z ziemi obcej do Polski. Losy żołnierzy Polskich sił Zbrojnych, którzy powrócili do kraju po II wojnie światowej, t. 2, Krzeszowice 2009.

Wojsko w Polsce "Ludowej”. Studia i materiały IPN, red. R. Klementowski et al., Wrocław 2011.

Wróbel J., Na rozdrożu historii, Łódź 2009.

Zmyślony W., Tragiczny koniec por. Śliwińskiego, „Gapa” 2012, nr 1.

\section{STRESZCZENIE}

\section{Grzegorz Sojda, Grzegorz Śliżewski, Polowanie na orły. Wstępny etap rozpracowania lotników byłych Polskich Sił Powietrznych przez Urząd Bezpieczeństwa w ramach operacji „Mewa” (1948-1949)}

Niniejszy artykuł jest próbą przedstawienia początków rozpracowania operacyjnego Urzędu Bezpieczeństwa skierowanego przeciwko powracającym do kraju lotnikom Polskich Sił Powietrznych. W okresie bezpośrednio po zakończeniu II wojny światowej do Polski wróciła niemal 1/4 żołnierzy PSP, którzy próbowali w kraju układać sobie życie na nowo. W tym okresie zainteresowanie UB lotnikami było incydentalne i prowadzone przez bezpiekę przy okazji rozpracowania wracających imigrantów. Miało ono charakter regionalny i nie było koordynowane przez Ministerstwa Bezpieczeństwa Publicznego aż do czerwca 1948 r., gdy odkryto działalność wywiadowczą por. pil. Władysława Śliwińskiego. Końcową cezurą niniejszego opracowania jest data wprowadzenia w życie nowych metod prowadzenia i dokumentowania rozpracowania lotników byłych Polskich Sił Powietrznych.

Słowa kluczowe: Władysław Śliwiński, Polskie Siły Powietrzne na Zachodzie, Urząd Bezpieczeństwa Publicznego, kryptonim „Mewa” 


\section{SUMMARY}

Grzegorz Sojda, Grzegorz Śliżewski, Hunting for eagles. The initial stage of the Security Office investigations into former Polish Air Force airmen in the „Seagull” („Mewa”) Operation

This study is an attempt to present the beginnings of the operational activities of the Security Office (Urząd Bezpieczeństwa, UB) against Polish Air Force airmen returning to the country. In the period immediately after the end of World War II, almost $1 / 4$ of Polish Air Force soldiers returned to Poland, trying to make a new beginning in the country. At that time, the interest of the UB in the aviators was incidental, and the activities of the security service were part of general spying on returning emigrants. They were of regional character and were not coordinated by the Ministries of Public Security until June 1948, when the intelligence activity of Lieutenant Pilot Władysław Śliwiński was discovered. The final caesura of this study is the date of the implementation of new methods of conducting and documenting the operational activity against former Polish Air Force aviators.

Keywords: Władysław Śliwiński, Polish Air Force in the West, Office of Public Security, codename „Seagull” („Mewa”)

\section{PEЗЮME}

Гжегож Сойда, Гжегож Слижевский, Охота на орлов.

Начальный этап обработки летчиков бывших польских ВВС службами безопасности в рамках операции „Чайка” (1948-1949).

Данная работа является попыткой представить начало оперативной работы служб безопасности, направленной против возвращающихся в страну летчиков польских ВВС. Сразу после окончания Второй мировой войны в Польшу вернулась практически одна четверть солдат польских военно-воздушных сил, которые пытались здесь заново построить свою жизнь. В этот период интерес служб безопасности к летчикам был окказиональный и проявлялся при работе служб с возвращающимися иммигрантами. Этот интерес имел региональный характер и не был координируем Министерством общественной безопасности вплоть до июня 1948 года, когда была обнаружена разведывательная деятельность поручика военно-воздушных сил Владислава Сливинского. Конечным поворотным пунктом этого исследования является дата внедрения новых методов ведения и документирования деятельности служб безопасности в отношении летчиков бывших польских ВВС.

Ключевые слова: Владислав Сливинский, польские военно-воздушные силы на западе, Управление общественной безопасностью, кодовое имя «Чайка" 